\title{
Modeling impacts of management alternatives on soil carbon storage of farmland in Northwest China
}

\author{
F. Zhang ${ }^{1,3,4}$, C. $\mathbf{L i}^{2}$, Z. Wang ${ }^{1,3}$, and $\mathbf{H}$. Wu ${ }^{1}$ \\ ${ }^{1}$ State Key Laboratory of Loess and Quaternary Geology, Institute of Earth Environment, CAS, Xi' an, 710075, PR China \\ ${ }^{2}$ Institute for the Study of Earth, Oceans, and Space, University of New Hampshire, Durham, NH 03824, USA \\ ${ }^{3}$ Graduate School, Chinese Academy of Sciences, Beijing, 100039, PR China \\ ${ }^{4}$ Xi' an JiaoTong University, Xi'an, 710049, PR China
}

Received: 16 January 2006 - Published in Biogeosciences Discuss.: 16 May 2006

Revised: 28 July 2006 - Accepted: 21 August 2006 - Published: 24 October 2006

\begin{abstract}
Long-term losses of soil organic carbon (SOC) have been observed in many agriculture lands in Northwest China, one of the regions with the longest cultivation history in the world. The decline of SOC contents not only impaired the soil fertility but also increased the amount of carbon dioxide $\left(\mathrm{CO}_{2}\right)$ emitted from terrestrial ecosystems into the atmosphere. However, quantifying the SOC losses at regional scale has long been remaining unsolved. A processbased model, Denitrification-Decomposition or DNDC, was adopted in the study to quantify impacts of farming management practices on SOC dynamics for a selected region, Shaanxi Province. The selected domain, with 3 million hectares of cropland across different climatic and farming management regimes, is representative for the major agricultural areas in Northwest China. The DNDC model was tested against long-term SOC dynamics observed at five agricultural sites in China. The agreement between the observed and modeled results indicate that DNDC was capable of capturing patterns and magnitudes of SOC changes across the climate zones, soil types, and management regimes in China. To quantify SOC dynamics for Shaanxi, we constructed a GIS database to hold all of the DNDC-required input information (e.g., weather, soil properties, crop acreage, and farming practices) for all the farmland in the studied domain. Sensitivity tests indicated the spatial heterogeneity of soil properties, especially initial SOC content, was the major source of uncertainty for the modeled SOC dynamics at regional scale. The Most Sensitive Factor (MSF) method was employed in the study to quantify the uncertainties produced from the upscaling process. The results from the regional simulations for Shaanxi indicated that (1) the overall 3 million hectares of farmland in the province was a source of atmospheric $\mathrm{CO}_{2}$ with $0.5 \mathrm{Tg} \mathrm{C} \mathrm{yr}^{-1}$ lost in 2000 under the current farming management conditions, (2) an increase in the rate of crop
\end{abstract}

$\overline{\text { Correspondence to: } \mathrm{C} . \mathrm{Li}}$

(changsheng.li@unh.edu) residue incorporation from $15 \%$ to $50 \%$ or $90 \%$ converted the farmland from the $\mathrm{C}$ source to a $\mathrm{C}$ sink with 0.7 or $2.1 \mathrm{Tg}$ $\mathrm{C} \mathrm{yr}^{-1}$ sequestered, respectively, and (3) applying farmyard manure at a rate of $500 \mathrm{~kg} \mathrm{C} \mathrm{ha}^{-1}$ also converted the cropland into a weak $\mathrm{C}$ sink with $0.2 \mathrm{Tg} \mathrm{C}$ sequestered in the farmland in Shaanxi. In the studied domain, crop residue and farmyard manure used to be the major sources of soil nutrients during the centuries-long cultivation history but were gradually abandoned since 1950 s when synthetic fertilizers became available. The results from this modeling study suggest that recovery of the traditional farming practices (i.e., residue incorporation and manure amendment) be a feasible approach to substantially improve the soil $\mathrm{C}$ status in the farmland of Shaanxi. The values of $\mathrm{C}$ gain or loss from this study for Shaanxi could vary if the modeled domain shifts to other provinces in Northwest China although the general conclusion may remain.

\section{Introduction}

Since the Industrial Revolution humankind came to realize the great impact of anthropogenic activities on earth systems. Driven by fossil fuel combustion, agricultural cultivation, deforestation and other human's activities, carbon (C) release from terrestrial ecosystems to the atmosphere has exceeded the range earth systems can adjust (Sun et al., 2001). It is estimated that the total terrestrial biosphere $\mathrm{C}$ pool is $2000 \mathrm{Gt}$ $\mathrm{C}$, which is approximately three times greater than the total amount of carbon dioxide $\left(\mathrm{CO}_{2}\right)$ in the atmosphere. The sum of carbon in dead biomass and soil organic carbon (SOC) pool is up to $1200 \mathrm{Gt}$ C (Falkowski et al., 2000). Soil organic carbon is one of the most important terrestrial pools for $\mathrm{C}$ storage, which affect atmospheric $\mathrm{CO}_{2}$ through $\mathrm{C}$ exchange at the soil-atmospheric interface (Cardon et al., 2001; Follett, 2001). Agro-ecosystem, accounting for $10 \%$ of the total terrestrial area, is one of the most sensitive terrestrial

Published by Copernicus GmbH on behalf of the European Geosciences Union. 
ecosystems suffering from heavy human disturbances. It has been widely observed that long term farming cultivation caused severe losses of soil carbon (Follett, 2001; Janzen et al., 1998; Sherrod et al., 2003; Wairiu and Lal, 2003; Wu et al., 2003). Conversion of natural prairies or forests to cultivated systems usually causes rapid depletion of the soil organic matter (Buyanovsky and Wagner, 1998). For example, field observations indicated about $40 \%-50 \%$ of soil carbon lost due to the transition from grassland to cultivated cropland at an agro-ecosystem in Australia (Grace, 1996). The emissions of $\mathrm{CO}_{2}$, methane and nitrous oxide from agriculture account for approximately one-fifth of the annual increment of radiative forcing globally (Cole et al., 1997). When changes induced by agriculture-related landuse involving biomass burning and soil degradation are included, the overall radiative forcing amounts to one-third of the anthropogenic impact. In addition, decrease in SOC storage leads to decline of soil fertility and hence threaten agroecosystem sustainability.

During the past two decades, a great amount of field and modeling studies have been conducted to demonstrate how to mitigate soil carbon loss by improving farming management practices such as tillage, residue incorporation, manure amendment etc. (Huggins et al., 1998; Janzen et al., 1998; Li, 1995; Li et al., 1994; Paustian et al., 2000; Sherrod et al., 2003). In fact, searching farming management alternatives for optimizing $\mathrm{C}$ biogeochemical cycle is becoming a main stream in agricultural studies in many countries (Buyanovsky and Wagner, 1998; Paustian et al., 2001; Post and Kwon, 2000). China possesses about $20 \%$ of world population but with only about $10 \%$ of world arable land (Chinese Environmental Status Bulletin, 2003). Due to the intensive cultivations in history, $57 \%$ of the cultivated soil subgroups or $31 \%$ of the total soil area in China have experienced significant carbon losses (Wu et al., 2003). Field observations of agricultural SOC depletion were reported for many locations in China (Li and Pan, 1999; Pan et al., 2003; Qiu et al., 2004; Wang et al., 2003). However, most of the reports stated the losses of SOC observed in individual fields with few estimates for regional or national scale. The soil degradation along with other problems such as decrease in total arable land, erosion, desertification etc., has brought an unprecedented tension to the Chinese agriculture (Pan and Zhao, 2005).

Field observations provide direct information about SOC pools and fluxes at specific sites. However, since SOC is highly dynamic in space and time driven by complex combinations of climate, soil and management conditions, quantifying SOC dynamics at regional or national scale through field measurements is inherently infeasible. Models were developed to try extrapolating the understandings gained at site scale to regional scale (Coleman et al., 1997; Peng et al., 1998; Schimel et al., 2000; Sellers et al., 1997). This kind of models, such as DNDC, Roth-C, TEM, Century, CASA etc., have been widely applied for SOC inventory or seques- tration in many regions (Smith et al., 1997). Basic processes of physics, chemistry and biology have been embedded in the models to enable them to simulate SOC accumulation and turnover across climate zones, soil types and management regimes. For this study on regional SOC dynamics for China, we selected the Denitrification-Decomposition (DNDC) model due to its limited requirement for input parameters as well as its successful applications in other countries (Brown et al., 2002; Butterbach-Bahl et al., 2001; Pathak et al., 2005). This paper reports how we tested and applied the model for quantifying impacts of farming management alternatives on SOC dynamics in a selected agricultural domain in Northwest China, which possesses the longest cultivation history in the world and is currently faced by SOC depletion.

\section{Materials and methods}

The $\mathrm{C}$ stored in soils is mainly in form of organic matter. SOC content is highly dynamic affected by ecological drivers (e.g., climate, vegetation, and anthropogenic activity), soil environmental factors (e.g., temperature, moisture, $\mathrm{pH}$, redox potential, and substrate concentration gradients), and biochemical or geochemical reactions (e.g., decomposition, assimilation, leaching etc.) (Li, 2000, 2001; Li et al., 2004). Process-based models are used to quantify SOC accumulation or turnover driven by the local climate, soil, vegetation and management conditions at the site scale. Geographic Information System (GIS) databases provide spatially differentiated information of climate, soil, vegetation, and management to drive the model runs across the region. To quantify the impacts of farming management alternatives on $\mathrm{C}$ sequestration from the 3 million hectares of cropland in the studied domain, we integrated a process-based model, DNDC, with a GIS database of cropland area, soil properties, cropping management (crop rotation, fertilizer use, irrigation, crop residue management, planting and harvest dates), and daily weather data.

\subsection{DNDC model validation}

DNDC is a biogeochemical model originally developed for predicting carbon sequestration and trace gas emissions for non-flooded agricultural lands. It simulates the fundamental processes controlling the interactions among ecological drivers, soil environmental factors, and relevant biochemical or geochemical reactions, which collectively determine the rates of trace gas production and consumption in agricultural ecosystems (Li et al., 1992, 1994). During the past decade, along with more international researchers involved in the modeling effort, DNDC has been substantially enhanced and become a generic agro-ecosystem model for predicting crop growth, $\mathrm{C}$ sequestration, greenhouse gas emissions, nitrate 
leaching, and water use efficiency for both upland and wetland crops.

DNDC consists of six sub-models, which simulate soil climate, plant growth, decomposition, nitrification, denitrification and fermentation, respectively. The soil climate submodel calculates soil temperature and moisture profiles based on soil physical properties, daily weather and plant water use. The plant growth submodel tracks crop growth and partitioning of the biomass into grain, stalk and roots. The decomposition submodel simulates decomposition of soil organic matter driven by the soil microbial respiration. The nitrification submodel calculates growth of nitrifiers and oxidation of ammonium to nitrate. The denitrification submodel operates at an hourly time step to simulate denitrification and the production of nitric oxide, nitrous oxide, and dinitrogen. The fermentation submodel simulates methane production and oxidation under anaerobic conditions. The six sub-models interact to enable DNDC to simulate a relatively complete suite of biochemical and geochemical processes occurring under both aerobic and anaerobic conditions. DNDC simulates SOC dynamics by tracking the turnover of four SOC pools, namely plant residue (or litter), microbial biomass, humads (or active humus), and passive humus. Each pool consists of two or three sub-pools with specific decomposition rates subject to temperature, moisture, redox potential and $\mathrm{N}$ availability in the soil. As soon as fresh crop residue is incorporated into the soil, DNDC will partition the residue into very labile, labile and resistant litter pools based on $\mathrm{C} / \mathrm{N}$ ratio of the residue. The lower the $\mathrm{C} / \mathrm{N}$ ratio, the more of the residue will be partitioned into very labile or labile pool. Each of the SOM pools has a specific decomposition rate subject to temperature, moisture and $\mathrm{N}$ availability. The organic matter in the litter pools will be broken down by the soil microbes. When the microbes die, their biomass will turn into humads pool. Humads can be further utilized by the soil microbes and turned into passive humus. During the sequential decomposition processes, a part of the organic $\mathrm{C}$ becomes $\mathrm{CO}_{2}$, and a part of the organic $\mathrm{N}$ becomes ammonium. By tracking the processes, DNDC quantifies SOM turnover in soils. Detailed management measures (e.g., crop rotation, tillage, fertilization, manure amendment, irrigation, weeding, and grazing) have been parameterized and linked to the various biogeochemical processes (e.g., crop growth, litter production, soil water infiltration, decomposition, nitrification, denitrification) embedded in DNDC (Li, 1995, 2000; Li et al., 1992, 1994, 1996, 2004).

The DNDC model has been independently tested and applied for soil $\mathrm{C}$ and $\mathrm{N}$ studies in North America, Europe, Asia and Oceania during the past 15 years although few validations were reported for China. The tests demonstrate that DNDC is capable of capturing the basic patterns and magnitudes of SOC variations or trace gas emissions across climatic zones, soil types and management regimes (Brown et al., 2002; Butterbach-Bahl et al., 2001; Cai et al., 2003; Grant et al., 2004; Kiese et al., 2004; Li et al., 1994;
Pathak et al., 2005; Saggar et al. 2003; Smith et al., 1997, 2004; Xu-Ri et al., 2003). In this study, five long-term (10-100 years) SOC datasets were collected across typical agricultural ecosystems in China (Fig. 1a). The measured SOC values with other relevant data (e.g., climate, soil properties, crop type and rotation, cropping practices etc.) from the sites were utilized for DNDC validations. The detailed information about the five sites is listed in Table 1.

\section{Case 1: A potato field in Hequ County, Shanxi Province}

Long-term (13 years) measurements on SOC were conducted at an experimental field in Hequ County, Shanxi Province in North China from 1988-2000. The site possessed typical continental climate with annual precipitation ranging from 220-520 mm. The local environmental conditions with frequent droughts and lack of irrigation water severely limited the crop yield as well the litter production. The experimental field was planted with potatoes under three different treatments (i.e., manure amendment, synthetic fertilizer application and control) during the experimental period (Duan et al., 2001). Field observations indicated that the three treatments had different impacts on the SOC dynamics during the 13 years. At the control plot where neither fertilizer nor manure was applied, the SOC content at the top soil $(0-20 \mathrm{~cm})$ decreased gradually from $0.0028 \mathrm{~kg}$ $\mathrm{C} / \mathrm{kg}$ to $0.0021 \mathrm{~kg} \mathrm{C} / \mathrm{kg}$ in $1988-2000$. At the plot with only synthetic fertilizer $(120 \mathrm{~kg}$ urea-N/ha) applied, SOC slightly increased from 0.0027 to $0.0029 \mathrm{~kg} \mathrm{C} / \mathrm{kg}$ during the 13 years. At the plot amended with farmyard manure $(22500 \mathrm{~kg} / \mathrm{ha})$, SOC increased from 0.0024 to $0.0040 \mathrm{~kg}$ $\mathrm{C} / \mathrm{kg}$ during the same period. Model simulations were conducted with the three management scenarios for the field. The modeled results captured the trends of SOC dynamics observed at the three plots (Fig. 2). The simulated results indicated that (1) the decrease in SOC at the control plot was mainly due to low input of the crop residue during the experimental period, (2) synthetic fertilizer application improved the crop biomass production and hence increased the litter incorporated into the soil, and (3) manure amendment substantially elevated SOC content through not only directly adding organic matter into the soil but also increasing litter production and incorporation. The observed and modeled results for the Hequ site are consistent with the long-term observations reported for a wheat field in the Rothemsted Agricultural Station in the UK (Jenkinson, 1991) although the climate and soil conditions were quite different between the two sites.

\section{Case 2: A corn field in Qujing County, Yunnan Province}

A 13-year (1978-1990) experiment was conducted at a corn field in Qujing County, Yunnan Province in southwestern China with typical subtropical climate conditions 
Table 1. Characteristics of the filed sites used for validation of DNDC.

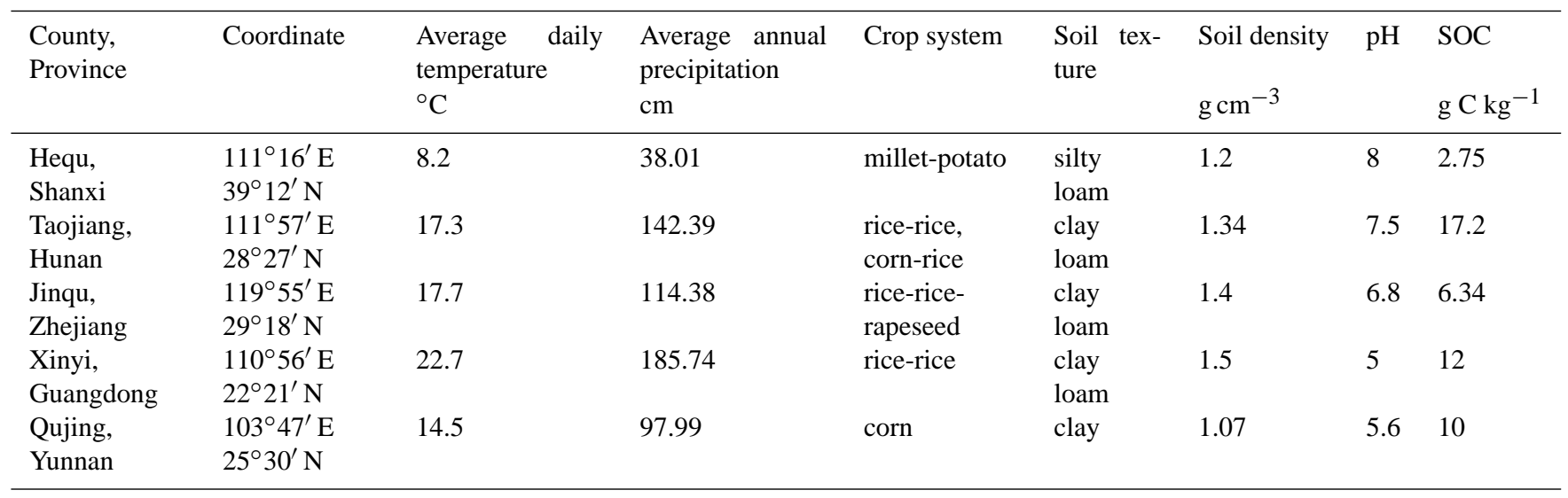

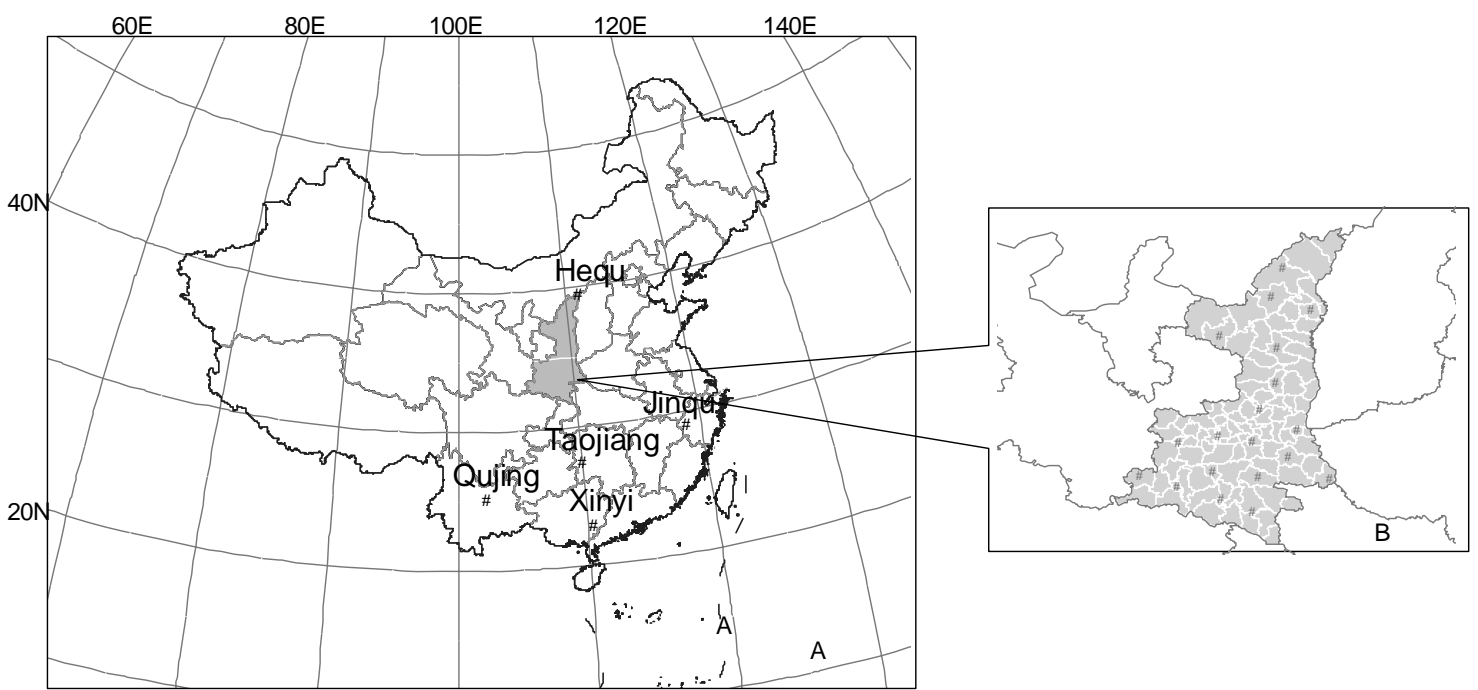

Fig. 1. Location of cropland sites for validation tests in China (a). The shadow part represents our research region, Shaanxi Province. Panel (b) shows the distribution of the 19 climate stations of Shaanxi.

(average annual precipitation $980 \mathrm{~mm}$ ). The field was divided into two plots with different treatments: farmyard manure $(30000 \mathrm{~kg} / \mathrm{ha}$ ) amendment and control (only $30 \mathrm{~kg}$ urea/ha used). There were significant inter-annual variations in the crop yields driven by precipitation. The field observations indicated that application of farmyard manure increased both the crop yield and SOC content. At the manure-treated plot, SOC contents increased from 0.0093 to $0.016 \mathrm{~kg} \mathrm{C} / \mathrm{kg}$ during the 13 years. In contrast, the SOC contents at the control plot only fluctuated between 0.0072 to $0.0094 \mathrm{~kg} \mathrm{C} / \mathrm{kg}$ during the same period of time (Dai et al., 1994). Simulations were conducted with DNDC for the two plots with local climate data and soil conditions. The modeled trends of SOC dynamics are in agreement with observations (Fig. 3). Modeled results indicated application of manure increased SOC through elevating crop litter production as well directly adding organic matter into the soil.

\section{Case 3: A triple-cropping system in Jinqu County, Zhejiang Province}

The Jinqu site possesses rice fields with different lengths of cultivation histories. Some of the fields have been used for rice production for about a century, and some were converted from upland crops only a couple of years ago. Before the conversion, most of the fields shared similar properties with relatively low SOC contents (about $0.007 \mathrm{~kg}$ $\mathrm{C} / \mathrm{kg}$ ). Sixty-six fields converted from upland crops to paddy rice 2-100 years ago were selected for observing impact of 


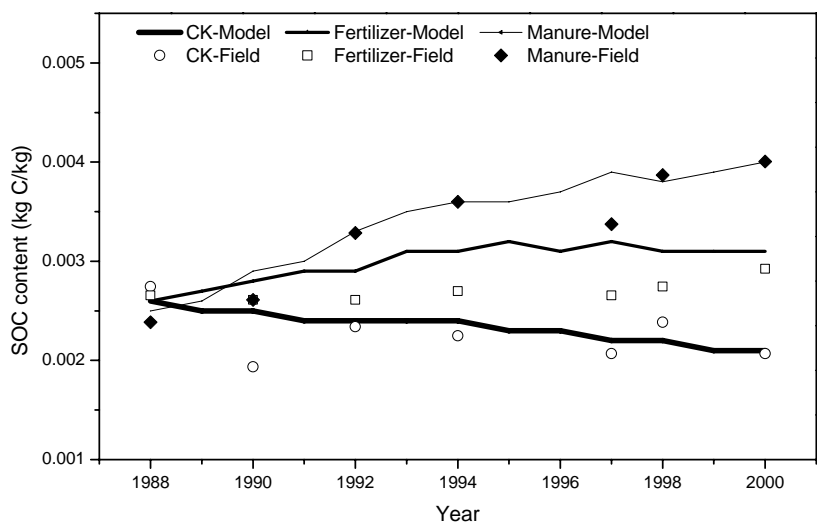

Fig. 2. Observed and modeled SOC dynamics at a potato field with three treatments (i.e., CK, control treatment; Fertilizer, synthetic fertilizer; Manure, manure amendment) in Hequ county, Shanxi Province, China from 1988-2000.

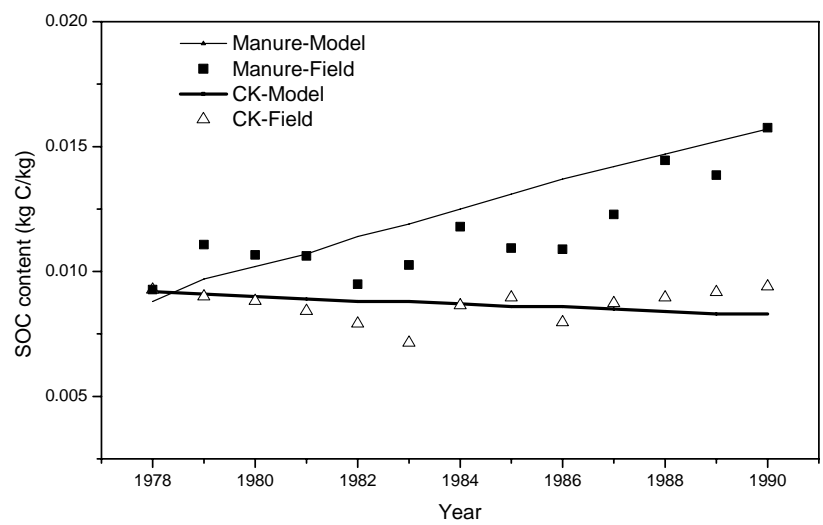

Fig. 3. Observed and modeled SOC dynamics at a corn field with two treatments (i.e., Manure, manure amendment; CK, control treatment) in Qujing county, Yunnan Province, China from 19781990.

the land-use change on SOC storage across the fields. The observations indicated that (1) the SOC in the paddy soils were unexceptionally higher than that in the upland soils, and (2) the SOC contents in the paddy soils increased along with increase in the years of rice cultivation (Zhang and $\mathrm{He}$, 2004). A 100-year scenario was designed to represent the typical farming practices for rice cultivation in the area, including the triple-planting system (i.e., annual rice-ricerapeseed rotation), $25 \%$ of crop residue incorporated, and farmyard manure amended in the early years of the rice cultivation. The modeled SOC content increasing along with the increase in the years of rice cultivation was in agreement with the observed results that SOC increased with the length of rice planting history (Fig. 4).

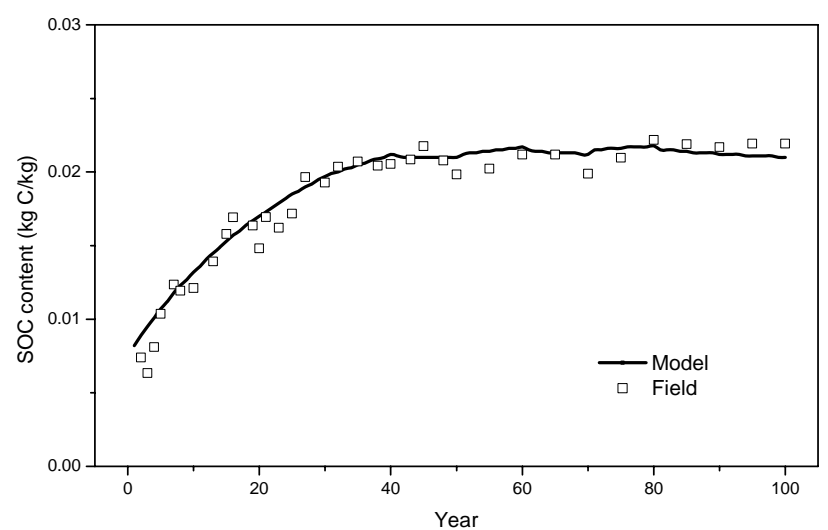

Fig. 4. A 100-year scenario representing 66 fields with the different time periods of rice cultivation was simulated with DNDC for Jinqu County, Zhejiang Province. The results indicated a rapid increase in SOC contents in the early stage of the conversion of upland crops to rice paddies in 1900-2000.

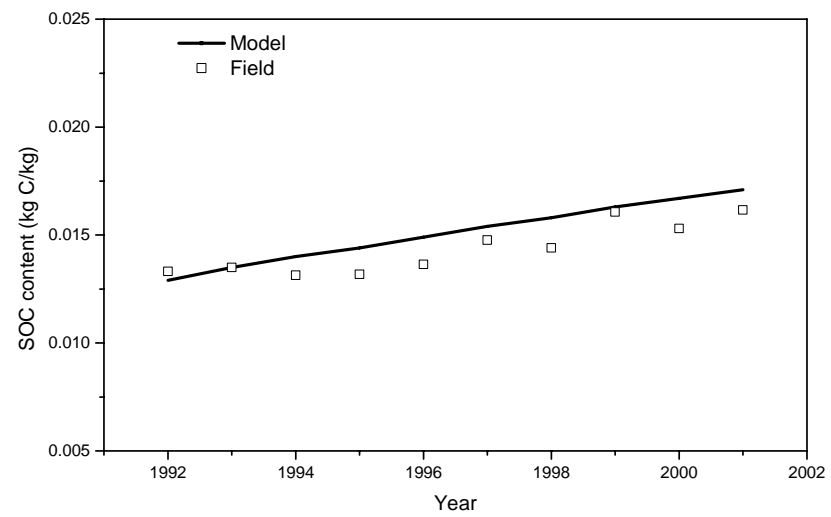

Fig. 5. Observed and modeled SOC dynamics at a double-rice field with synthetic fertilizers and manure applied in Xinyi County, Guangdong Province in 1992-2001.

\section{Case 4: A double-rice field in Xinyi County, Guangdong Province}

Xinyi County is located at south of China with typical monsoon climate. Long-term field measurements of SOC were conducted at a site with double-rice system in the county from 1992-2001 (Tang, 2003). Field data indicated the SOC content increased from 0.013 to $0.016 \mathrm{~kg} \mathrm{C} / \mathrm{kg}$ under the local farming management conditions with both synthetic fertilizer ( $140 \mathrm{~kg}$ urea-N/ha) and manure $(2800 \mathrm{~kg} / \mathrm{ha})$ applied during the 10 -year period. We run DNDC with the local climate, soil and management conditions for the site. The modeled results are in agreement with observations (Fig. 5). 


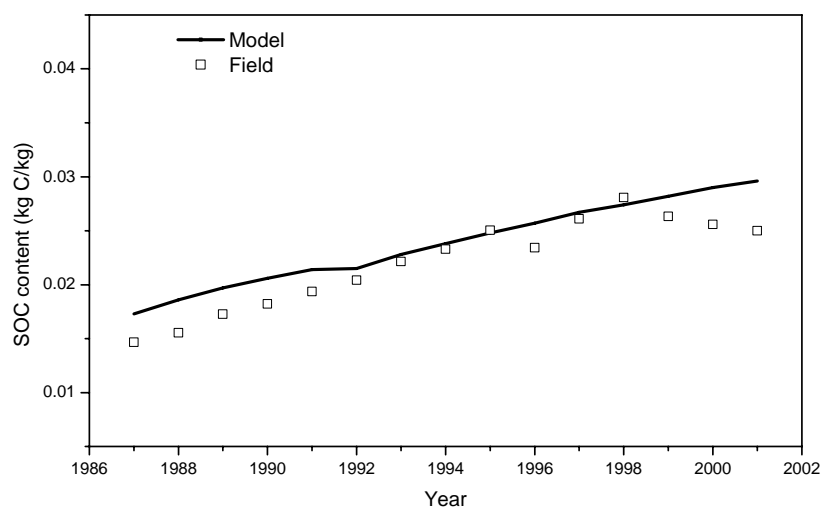

Fig. 6. Observed and modeled SOC dynamics at a rice-upland crops rotated field with synthetic fertilizers and manure applied in Taojiang County, Hunan Province in 1987-2001.

\section{Case 5: An upland crops-rice rotated field in Taojiang County, Hunan Province}

Fifteen-year (1987-2001) measurements were conducted at an experimental station in Taojiang County, Hunan Province with a focus on long-term variation in the soil fertility. The field was planted with rice rotated with corn, barley and vegetables in years 1988-1991, 1992-1997 and 1998-2001, respectively. The field received $160 \mathrm{~kg}$ fertilizer-N/ha and $5000 \mathrm{~kg}$ manure-C/ha annually. The SOC content at the site increased rapidly from 0.0015 to $0.0028 \mathrm{~kg} \mathrm{C} / \mathrm{kg}$ during the experimental period (Fu et al., 2003). Driven by the local climate, soil and management conditions, DNDC captured the magnitude and pattern of the SOC dynamics observed at the site (Fig. 6).

The above-described five cases represented a wide range of agro-ecosystems in China. The validation tests against the observations proved applicability of DNDC for predicting SOC dynamics across climate zones, soil types, and management regimes for China. The ability of DNDC in capturing impacts of farming practices on SOC dynamics is based on the processes embedded in the model, which allow it to precisely track the impacts of the litter addition on a series of soil $\mathrm{C}$ pools and fluxes as shown in Figs. 7 and 8. The two figures show how manure amendment or crop residue incorporation affected the SOC pools of litter, microbe, humads and humus as well $\mathrm{CO}_{2}$ emissions for a selected field at the Hequ site in Shanxi Province. In Fig. 7, when $3000 \mathrm{~kg}$ farmyard manure- $\mathrm{C} / \mathrm{ha}$ was added into the soil by the end of April, the manure was immediately partitioned into the soil resistant litter and humads pools based on $\mathrm{C} / \mathrm{N}$ ratio of the manure. Driven by the soil microbial assimilation, the resistant litter and humads continuously decomposed although with different rates during the following months. When the soil microbes dead and decomposed, a part of the organic $\mathrm{C}$ in the microbes became $\mathrm{CO}_{2}$ emitted into the atmosphere and a part of the organic $\mathrm{C}$ was transferred into the humads pool.
Through further decomposition, the humads became humus. Sine either the microbial C pool or the humads pool has a relatively quick turnover rate, the sizes of the two pools remain relatively stable across the season. The lost $\mathrm{C}$ through the decomposition of litter and humads was mainly emitted as $\mathrm{CO}_{2}$ into the atmosphere. After harvest, the fresh crop residue (e.g., roots and above-ground litter) were incorporated into the soil that increased the sizes of the labile and resistant litter pools again. During the entire season, the humus pool had a net increase. This pool possesses passive SOC with very low rate of decomposition. Figure 8 demonstrates the impacts of straw incorporation on the SOC pools. Differing from manure amendment, straw didn't contain humads and could bring only litter into the soil. The added straw was partitioned into labile and resistant litter pools based on the $\mathrm{C} / \mathrm{N}$ ratio of straw. Along with decomposition of the labile and resistant litter, their pools gradually reduced, and most of their organic $\mathrm{C}$ became $\mathrm{CO}_{2}$, and a part of the organic $\mathrm{C}$ finally entered the humus pool through the microbial assimilation and decomposition. The two figures illustrate the general patterns of impacts of manure amendment or crop residue incorporation on the SOC pools although their dynamics are also subject to other environmental conditions such as the soil temperature, moisture, tillage disturbance etc.

\subsection{Sensitivity tests}

A series of sensitivity tests were conducted to demonstrate how the DNDC-predicted SOC dynamics respond to variations in the input parameters related to climate, soil and management. A typical corn field in Changwu County, Shaanxi Province was selected for constructing a baseline scenario for the tests. A 10-year baseline scenario was composed based on the local 1988-1997 weather data as well as the local soil and management conditions in the county (see details in Table 2). The 10-year average annual precipitation was $496.6 \mathrm{~mm}$ with the maximum $(720.7 \mathrm{~mm})$ in 1996 and the minimum $(313.6 \mathrm{~mm})$ in 1997 . Alternative scenarios were designed by varying each of the climate, soil or management factors in their ranges commonly observed in Northwest China (Table 2).

Ten-year simulations were conducted with the baseline and alternative scenarios. A mean annual change in SOC content was calculated for each simulation. Based on the difference in the mean annual SOC changes between the baseline and alternative scenarios, we quantitatively determined the impact of a variation in a single environmental or management factor on the mean annual change in SOC content. The results from the sensitivity tests indicate that (1) among the environmental factors, initial SOC content is the most sensitive factor for regulating SOC sequestration rate, and (2) among the management factors, crop residue incorporation and manure amendment are the most sensitive factors affecting the SOC dynamics (Fig. 9). The results are in agreement with the general understanding of SOC dynamics in 
DNDC-Simulated Daily Dynamics of Soil C Pools in a Crop Field with Manure Amendment at Hequ Site

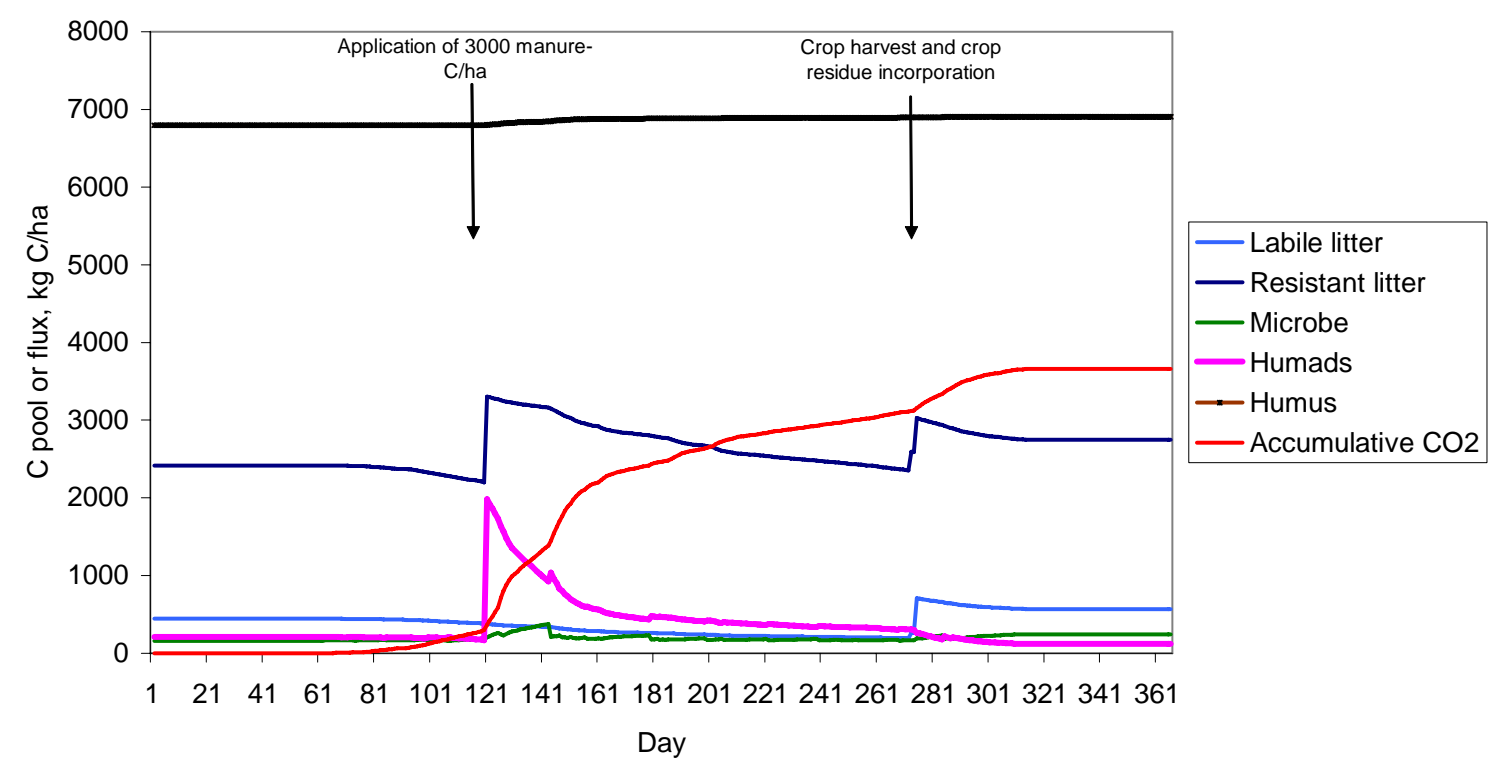

Fig. 7. Impacts of manure amendment on SOC pools during a one-year simulation for a millet field at Hequ County, Shanxi Province.

DNDC-Simulated Daily Dynamics of Soil C Pools in a Crop Field with Straw Amendment at Hequ

Site

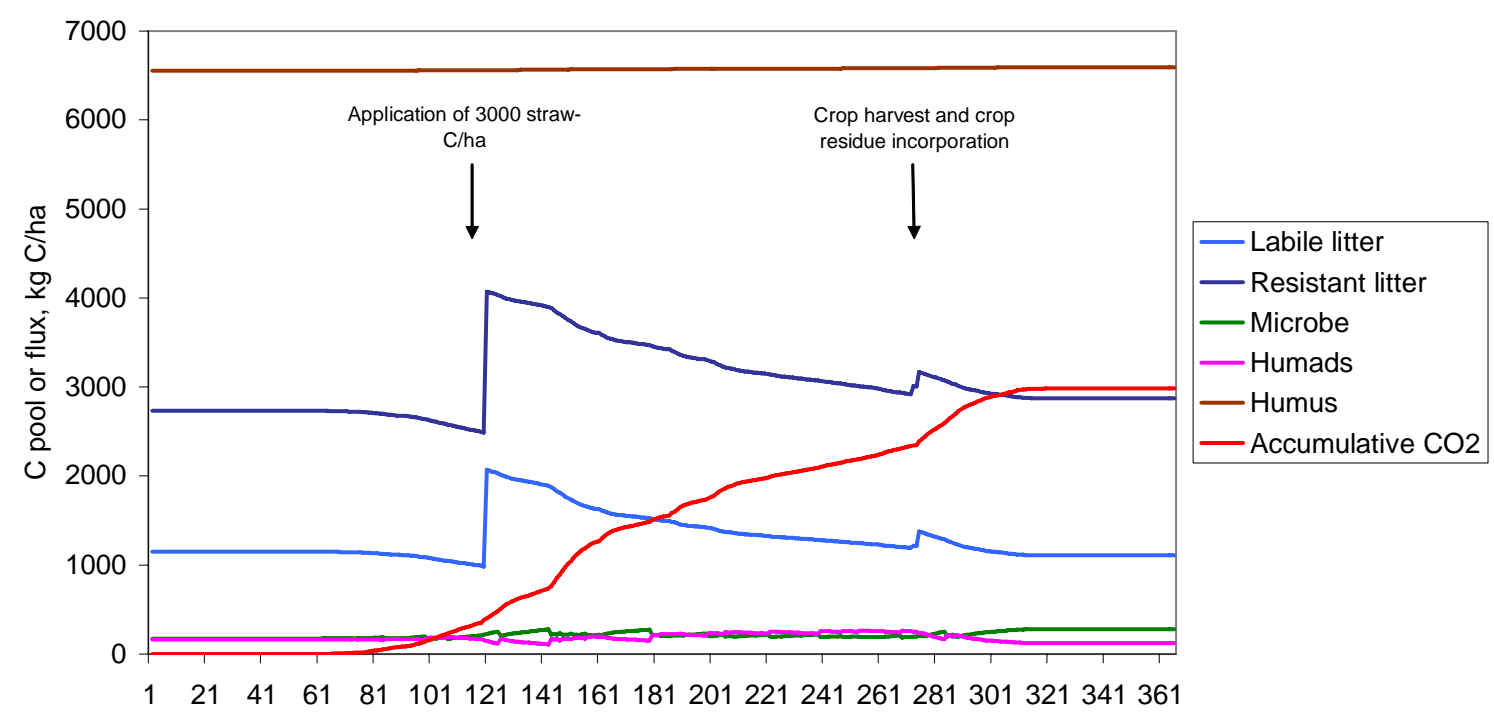

Day

Fig. 8. Impacts of straw incorporation on SOC pools during a one-year simulation for a millet field at Hequ County, Shanxi Province.

agro-ecosystems where SOC storage is basically controlled by the balance between the SOC gain through crop residue or manure incorporation and the SOC loss through decomposition, the rate of which is fundamentally determined by the initial size of SOC pool (Li et al., 1994; Smith et al., 1997).
Results from the sensitivity tests have a dual implication, which indicate that (1) there are potentials for enhancing SOC sequestration through alternative management practices and (2) SOC dynamics is sensitive to some input factors (e.g., initial SOC content, crop residue incorporation, 
Table 2. Baseline and alternative scenarios for sensitivity tests.

\begin{tabular}{ll}
\hline Scenario & Conditions or Variations \\
\hline Baseline & Climate: $1988-1997$ daily temperature and precipitation data with mean annual \\
& temperature $11.2^{\circ} \mathrm{C}$ and precipitation $496.6 \mathrm{~mm}$ \\
& Soil: clay loam, $\mathrm{SOC} 1 \%, \mathrm{pH} 8.2$, bulk density 1.4. \\
& Crop: corn, planted on $1 \mathrm{May}$ and harvest on October 1 \\
& Residue incorporation: $15 \%$ \\
& Tillage: conventional tillage (tilling twice to depth $10 \mathrm{~cm})$ \\
& Fertilization: $120 \mathrm{~kg}$ urea-N/ha per year, no manure applied \\
& Irrigation: irrigation index $=$ irrigated fraction of land \\
& Decrease (TD) by $3{ }^{\circ} \mathrm{C}$ and $6^{\circ} \mathrm{C}$ and increase $(\mathrm{TI})$ by $3^{\circ} \mathrm{C}$ and $6^{\circ} \mathrm{C}$ \\
Change in temperature & Decrease (PD) by $10 \%$ and $20 \%$ and increase $(\mathrm{PI})$ by $10 \%$ and $20 \%$ \\
Change in precipitation & silt loam $(\mathrm{SiL})$, loam $(\mathrm{L})$, sandy clay loam $(\mathrm{SCL})$, Silty clay loam $(\mathrm{SiCL})$, sandy \\
Change in soil texture & clay (SC), silty clay $(\mathrm{SiC})$, clay $(\mathrm{C})$ \\
& $0.005,0.015,0.02,0.025 \mathrm{~kg} \mathrm{C} / \mathrm{kg}$ \\
Change in initial SOC content & $10 \%, 50 \%, 80 \%$ \\
Change in crop residue incorporation & $60,90,150,180 \mathrm{~kg} \mathrm{~N} / \mathrm{ha}$ \\
Change in fertilizer application rate & $500,1000,1500 \mathrm{~kg} \mathrm{C} / \mathrm{ha}$ \\
Change in manure application rate & $0.2,0.4,0.6,0.8,1.0$ \\
Change in irrigation index &
\end{tabular}

Impacts of Environmental and Management Factors on Change in Soil Organic Carbon (SOC) Content

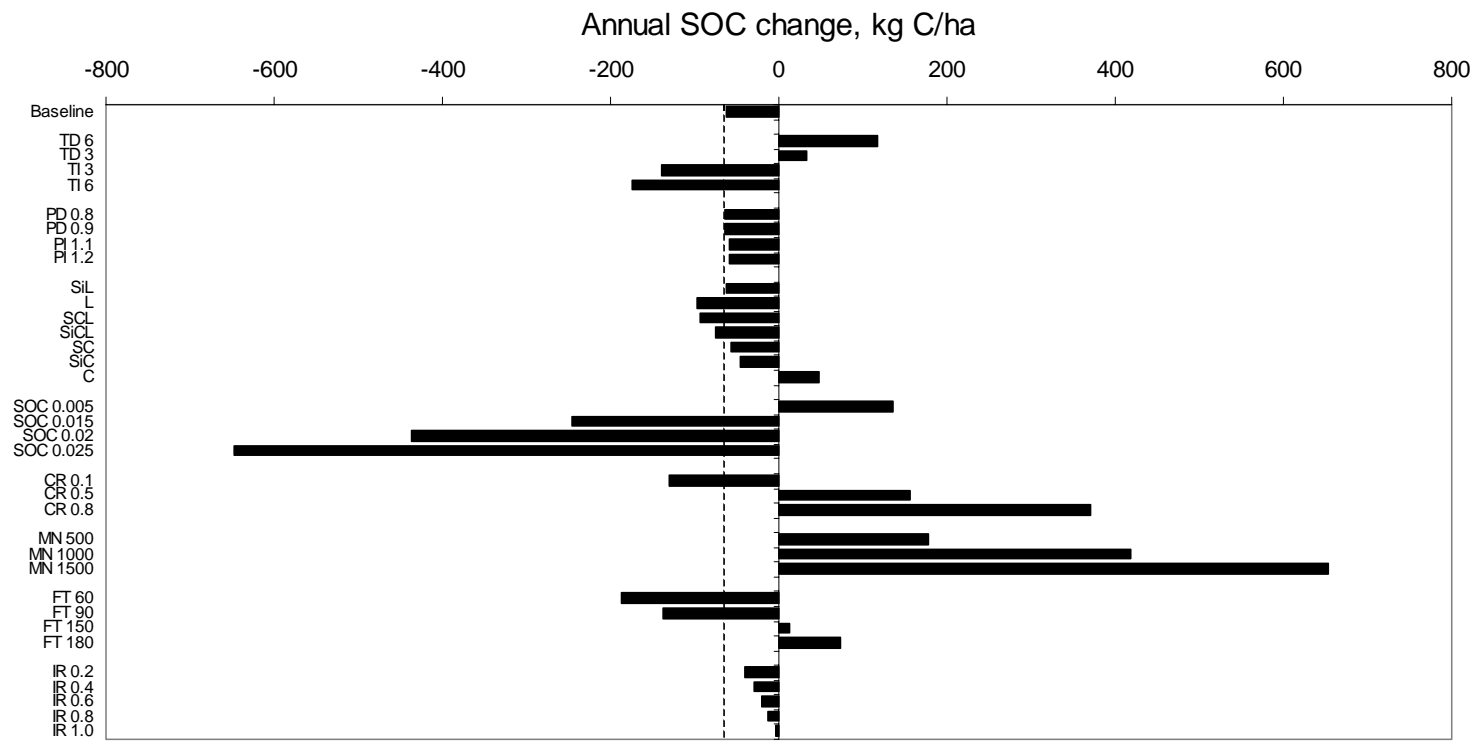

Fig. 9. Results from sensitivity tests by varying each single environmental or management factor in its range commonly observed in agricultural areas in Northwest China. Among the environmental factors, initial SOC content is the most sensitive factor determining the SOC sequestration or loss rate. Among the management factors, crop residue incorporation and manure amendment can significantly affect the SOC dynamics. The dot line indicates the annual SOC change $(-63 \mathrm{~kg} \mathrm{C} / \mathrm{ha})$ under the baseline conditions. (abbreviation: TD, decrease temperature by $3^{\circ} \mathrm{C}$ and $6^{\circ} \mathrm{C}$; TI, increase temperature by $3^{\circ} \mathrm{C}$ and $6^{\circ} \mathrm{C}$; PD, decrease precipitation to $80 \%$ and $90 \%$; PI, increase precipitation to $110 \%$ and $120 \%$; SOC, initial SOC content; CR, crop residue application; MN, manure amendment; FT, synthetic fertilizer application; IR, irrigation index).

manure amendment) more than others. The latter should have brought us a clear message that the most sensitive fac- tors for modeling SOC dynamics should be given a high priority during the input data acquisition as they could make 
more contributions to the uncertainties produced during the upscaling process. In fact, we have applied this conclusion for our database construction as described in the next section.

\subsection{Database construction in consideration of uncertainty analysis}

Shaanxi Province was selected as a modeled domain for this study due to its typical climate, soil and agricultural management conditions for Northwest China. Shaanxi Province is located in the eastern edge of Northwest China with complex landforms and continental climates. The province consists of three major agricultural zones distinguished with different climate conditions as well as farming management regimes. The northern zone $\left(\mathrm{N} 34^{\circ} 15^{\prime} \sim 39^{\circ} 25^{\prime}\right)$ is base on the Loess Plateau with typical continental climate. Only upland crops are planted in the zone. Droughts are the main factor limiting the crop yields due to the limited precipitation as well the lack of water resources for irrigation. The middle zone $\left(\mathrm{N} 33^{\circ} 51^{\prime} \sim 35^{\circ} 37^{\prime}\right)$ is located on the alluvial plain along the Wei River where there are well-developed irrigation systems to provide adequate water from either the river or groundwater to support the prosperous agriculture in the zone. The southern zone $\left(\mathrm{N} 31^{\circ} 43^{\prime} \sim 34^{\circ} 23^{\prime}\right)$ consists of scattered farmlands spread on the southern slope of the Qin-Ling Mountains where the monsoonal climate provides relatively warm weather and abundant rainfalls to the crops. Upland crops such as winter wheat, corn, rapeseeds etc. are dominant in the northern and middle zones while paddy rice is a popular crop for the southern zone. However, under the demands of the ever increasing population as well as the rapid development of local economy, all of the farmlands in the three zones have been experienced intensive cultivations during the past 5 or 6 decades. A lot of traditional farming practices, such as incorporation of crop residue or manure amendment, which had maintained the soil fertility for centuries, were gradually abandoned since 1950s when synthetic fertilizers became available. For example, burning crop residue in site after harvest is a common practice across the entire Northwest China that substantially diminished the litter incorporation in the soils. In addition, under the new social-economic conditions amendment of farmyard manure, which requires more labor work, is almost totally abandoned. These changes in farming management, which have inherently accelerated SOC losses from the local farmland, were included in our database to support the model simulations.

To support the DNDC runs at regional scale for the selected domain, a Geographic Information System (GIS) database was constructed to hold the spatially differentiated information of climate, soil and farming management for all of the croplands in Shaanxi. Year 2000 was selected as the baseline year for the study. Since the data of crop census were provided at a county scale, county was selected as the basic simulated unit to maintain the accuracy of the original acreage information.

\subsubsection{Crop data}

In 2000, Shaanxi had 3 million hectares of cropland mainly planted with corn, winter wheat, rice, soybeans, oats, cotton, potatoes, and millet. Forty-five cropping systems including 19 single-, 24 double- and 2 triple-cropping systems were practiced for the croplands across 107 counties in Shaanxi (Shaanxi Department of Agriculture, 1987; Yang, 2001). Farming management information was collected from various sources reporting tillage, fertilization, irrigation and other practices for Northwest China (e.g., Shan and Chen, 1993; Peng, 2001).

\subsubsection{Climate data}

Weather data (daily maximum and minimum temperature, and daily precipitation) of year 2000 from 19 climatic stations within the Shaanxi province were collected from National Meteorological Agency of China and http://www.ntsg. umt.edu/personnel/mattj/bgc_extract.htm. Each of the climatic stations was assigned to a cluster of counties based on their geographic locations (Fig. 1b). Figure 10 shows the mean daily temperature and annual precipitation for Shaanxi in 2000. Both temperature and precipitation decreased from the south to the north of the province. Mean daily temperature is between $6-12^{\circ} \mathrm{C}$ for Northern Shaanxi, and $12-17^{\circ} \mathrm{C}$ for Southern Shaanxi. Most of the areas in the north have mean annual precipitation less than $400 \mathrm{~mm}$. The precipitation in the middle and southern zones varies from 400 to $1130 \mathrm{~mm}$ per year.

\subsubsection{Soil data}

DNDC requires four soil properties (i.e., bulk density, SOC content, texture and $\mathrm{pH}$ ) as input parameters to drive the model simulations. The soil data adopted in our databases were collected from the National Soil Atlas of China (1:14 000 000, Institute of Soil Science, 1986) and calibrated with other sources (e.g., National Soil Survey Office of China 1993-1997).

The soil data were relatively coarse that would constitute a major source of uncertainty for the regional estimation. Following a routine adopted by most regional modeling studies, our domain, Shaanxi, was divided into many polygons or grid cells with an assumption that each grid cell is uniform in all its properties. This assumption is against the fact that soil properties usually vary even within small scales such as a county or a farm. Averaging the variations of soil properties may not resolve the problem as the correlation between SOC dynamics and any of the soil properties is nonlinear. To accommodate the challenge induced from the soil heterogeneity, we adopted the Most Sensitive Factor (MSF) method developed by $\mathrm{Li}$ and his colleagues ( $\mathrm{Li}$ et al., 1996, 2001, 2004). As indicated by the above-described sensitivity tests, some soil properties, especially initial SOC 


\section{Climate condition of Shaanxi in 2000}

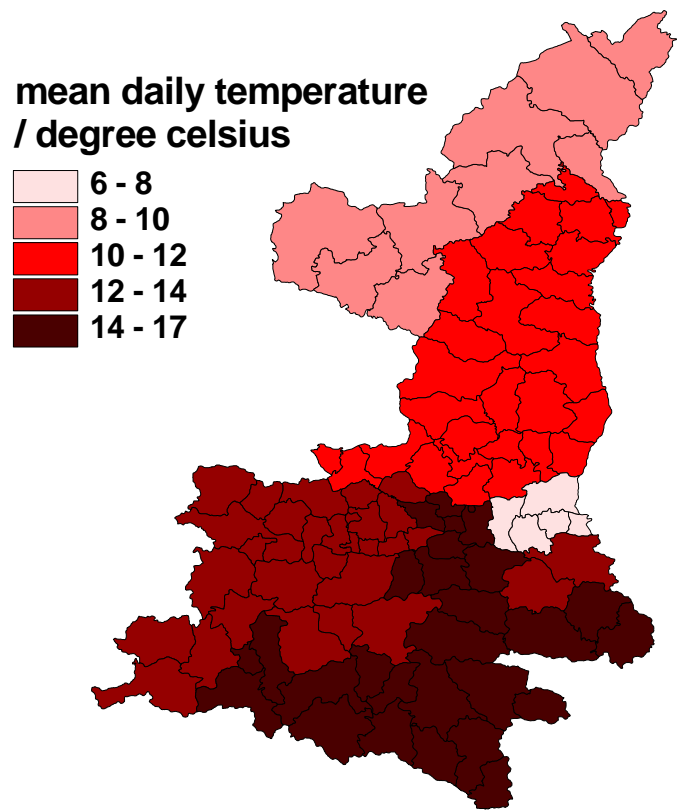

200

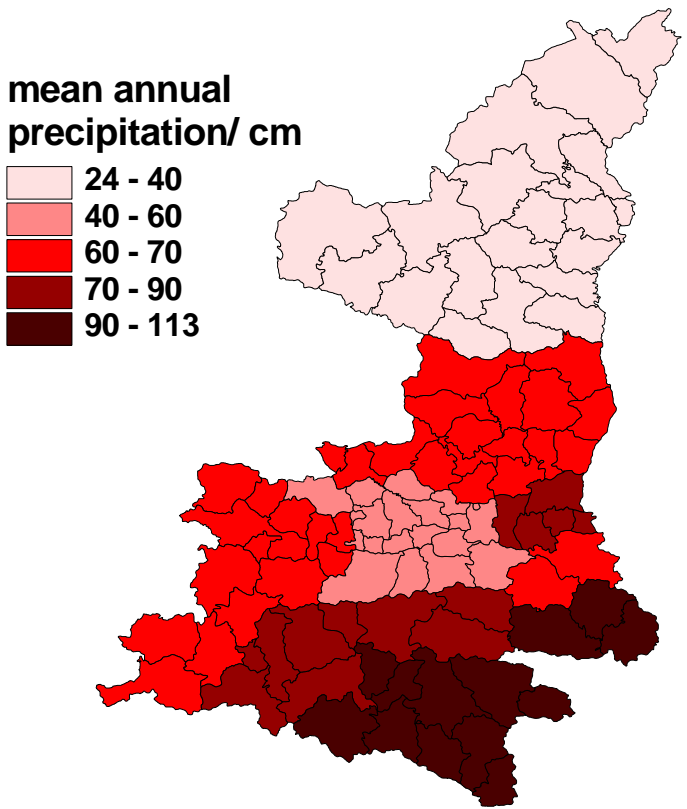

$\mathrm{N}$

400 Kilometers

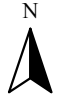

Fig. 10. Distribution of daily temperature and annual precipitation across Shaanxi in year 2000. Daily temperature was showed as mean value. Data were provided by National Meteorological Agency of China.

content, are the most sensitive factors for estimating SOC dynamics. Based on the MSF method, we assigned each soil factor (i.e., bulk density, texture, $\mathrm{SOC}$ contents or $\mathrm{pH}$ ) for each grid cell (i.e., each county for this study) with two values, the maximum and minimum values observed within the county. During the model simulations, DNDC ran twice for each cropping system in each county with the two extreme values of the most sensitive factor (i.e., initial SOC content for this study). The two runs produced two fluxes (i.e., annual SOC change) to form a range, which was assumed to be wide enough to include the "real" flux with a high probability. This methodology has been verified against the Monte Carlo method, a classical tool for sensitivity test. The results indicated more than $90 \%$ of the SOC changes predicted with the Monte Carlo method were located within the range produced by the MSF method (Li et al., 2004). By constructing our GIS database with the maximum and minimum values for soil texture, SOC content, bulk density and $\mathrm{pH}$, we brought the uncertainties induced by soil heterogeneity under control.

Maps of soil properties (e.g., mean values for clay fraction, soil $\mathrm{pH}$, SOC content and bulk density) for Shaanxi are shown in Fig. 11. Clay fraction varied from 3\% to 30\% across the province with higher values in the southern zone. The soils in the cropland of Shaanxi are basically neutral with a little alkaline in the northern zone and a little acidic in the southern zone. The geographic distribution of SOC contents in Shaanxi was highly uneven. Contents of SOC varied from $0.003-0.02 \mathrm{~kg} \mathrm{C} / \mathrm{kg}$ within the provincial scope. The soils relatively rich in SOC $(0.01-0.02 \mathrm{~kg} \mathrm{C} / \mathrm{kg})$ were mainly distributed in the southern zone, especially along the southern slope of the Qin-Ling Mountains with relatively warm and humid climates. The soils with the lowest SOC $(<0.004 \mathrm{~kg}$ $\mathrm{C} / \mathrm{kg}$ ) were mostly located in the northern counties with typical arid or semiarid climates.

\subsection{Upscaling}

We conducted county-scale simulations with DNDC for all cropping systems in all counties in Shaanxi Province. During the simulations, input parameters including daily weather data, soil properties, crop acreage, crop types and rotations, and farming practices (e.g., tillage, fertilization, manure amendment, and irrigation) for each county were read out from the GIS database; and the simulated daily and annual changes in SOC content were recorded for each cropping system in each county. Each cropping system was simulated twice with the maximum and minimum values of initial SOC content for each county to produce a pair of annual 

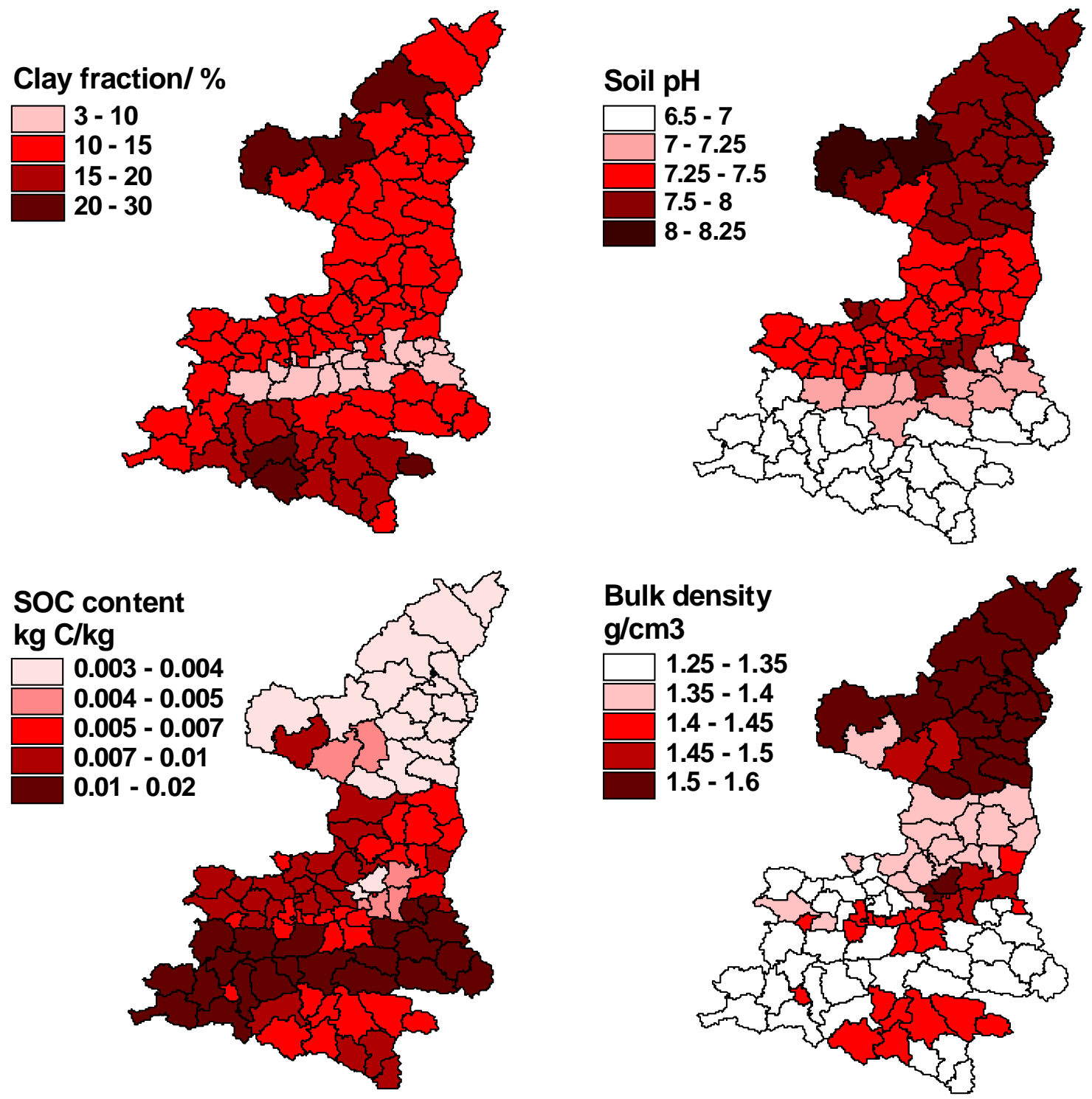

\section{Bulk density g/cm3}
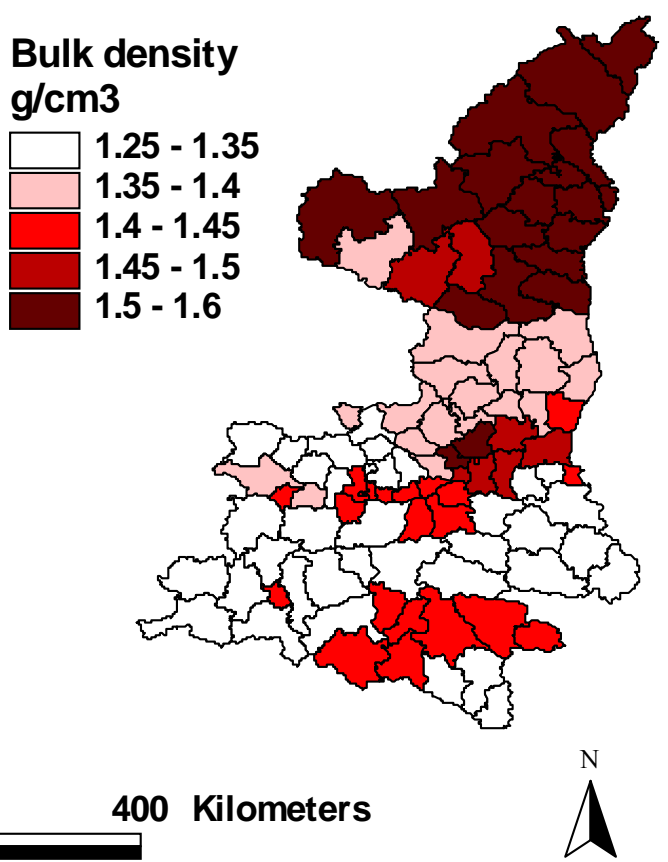

Fig. 11. Distribution of four main soil properties (clay fraction, soil $\mathrm{pH}$, bulk density and initial SOC content) of cropland across Shaanxi in year 2000. All the contents of the soil properties show gradient change trend.

changes in SOC for the cropping system in the county. Total change in SOC for a county was calculated by summing up the SOC changes for all of the cropping systems in the county. The provincial change in SOC is the sum of the SOC changes in all the counties. The DNDC model did not estimate SOC loss due to physical erosion, so the modeled results represent a conservative estimate of SOC losses in the domain.

A baseline and three alternative scenarios were designed to represent the current and altered cropping management prac- tices for the regional predictions. The baseline scenario was composed based on the actual cropping management practices commonly applied in Northwest China. In the baseline scenario, the cropland was conventionally tilled with $15 \%$ of aboveground crop residue incorporated in the soils. Based on the reported county-scale data for Shaanxi in 2000, Nfertilizer application rates varied greatly $(30-250 \mathrm{~kg} \mathrm{~N} / \mathrm{ha})$ from county to county due to the uneven accessibilities of the farmers to fertilizer. The spatially differentiated fertilizer application rates were recorded in the GIS database for all 
the counties. There was no manure used for the baseline scenario. An irrigation index was calculated based on the irrigated fraction of total farmland in the county. Three alternative management scenarios were designed to test the impacts of increases in crop residue incorporation rate and application of manure. Crop residue as well farmyard manure used to be the major sources of nutrients for agricultural soils in China before 1950s. Since then synthetic fertilizer became available in China that made manure use substantially decreased. Based on the official report of China, only $15 \%$ of above-ground crop residue was incorporated in the soils after harvest (Ministry of Agriculture, 1997). Most of the residue was burned or moved from the fields. We designed two alternative scenarios, CR1 and CR2, to represent the increases in crop residue incorporation rates to $50 \%$ and $90 \%$, respectively. Another alternative scenario was designed to represent application of farmyard manure. In 2000, there were 1.5, 6.3 and 8.8 million heads of cattle, sheep and pigs, respectively, in Shaanxi, which produced about 5.1 million tons of dry matter of manure per year. By assuming about half of the manure could be finally used for land application, each hectare of cropland in Shaanxi would receive $850 \mathrm{~kg}$ manure (equivalent to $500 \mathrm{~kg}$ manure $\mathrm{C}$ ). We composed scenario MN to represent manure amendment at a rate of $500 \mathrm{~kg} \mathrm{C} / \mathrm{ha}$ per year for all the cropping systems in the modeled domain.

By comparing the modeled annual changes in SOC between the baseline and the three alternative scenarios, we quantified the impacts of the farming management alternatives on SOC dynamics at the regional scale.

\section{Results}

The simulations with DNDC for 3 million hectares of farmland with 45 cropping systems in Shaanxi produced spatially differentiated SOC storage as well annual SOC changes for 107 counties in the domain. Total SOC storage and its variations under either the baseline or the alternative management conditions were calculated to quantify the role of the entire farmland of Shaanxi in atmospheric $\mathrm{CO}_{2}$ sequestration.

\subsection{Storage of SOC}

Modeled results indicated that total SOC content $(0-50 \mathrm{~cm})$ in all cropland of Shaanxi was $55-150 \mathrm{Tg} \mathrm{C}$ with a mean $103 \mathrm{Tg} \mathrm{C}$. The modeled results indicated that the sharp contrast on SOC contents between the southern and northern counties attribute to not only the climatic conditions but also farming management practices (Fig. 11). In the southern counties, double-cropping systems were prevailing that produced more crop residue to sustain the relatively high SOC levels. In addition, paddy rice was a popular crop in the southern counties that was favorable for sustaining the high SOC levels under the season-long anaerobic conditions in the soils. In the northern counties, low precipitation and insuf- ficient irrigation facilities limited the crop yields as well litter production that lowed down the SOC equilibrium. The modeled results indicated that the geographic distribution of SOC at present resulted from the collective effects of climate, land-use history and current farming management practices.

\subsection{Impacts of management alternatives}

Annual changes in SOC contents simulated with the baseline and alternative management scenarios were calculated for each county as well for the entire province. The differences in the annual SOC changes between the baseline and alternative scenarios were utilized to represent the impacts of the farming management alternatives on SOC dynamics at the county or provincial scale. The results indicated that all the three alternative scenarios (i.e., increase in crop residue incorporation rate from $15 \%$ to $50 \%$ and $90 \%$, and manure application at rate of $500 \mathrm{~kg} \mathrm{C} / \mathrm{ha}$ ) converted the Shaanxi farmland as a whole from a source to a sink of atmospheric $\mathrm{CO}_{2}$ by increasing $\mathrm{C}$ sequestration rates in the soils.

With the present farming practice defined in the baseline scenario, the annual changes in SOC storage in the Shaanxi farmlands ranged from -2.1 to $1.0 \mathrm{Tg} \mathrm{C} \mathrm{yr}^{-1}$ with a mean $-0.5 \mathrm{Tg} \mathrm{C} \mathrm{yr}^{-1}$. High rates $(>1400 \mathrm{~kg} \mathrm{C} / \mathrm{ha}$ ) of SOC losses occurred in the southern counties, which possessed relatively high initial contents of SOC. In contrast, the soils in most northern counties slightly gained SOC where the initial SOC contents were relatively low. In the modeled domain, there were 32 counties gaining SOC and 75 counties losing SOC under the baseline management conditions (Fig. 12). In general, the overall farmlands in Shaanxi were a weak source of atmospheric $\mathrm{CO}_{2}$ in 2000. By elevating the rate of crop residue incorporation to $50 \%$, the annual change in SOC stor-

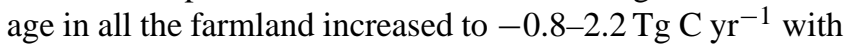

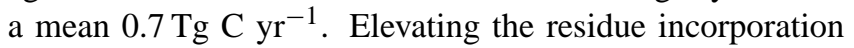
rate to $90 \%$ increased the annual SOC change to $0.6-3.5 \mathrm{Tg}$

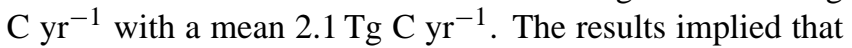
increases in crop residue incorporation converted the farmlands from a source to a sink of atmospheric $\mathrm{CO}_{2}$ by substantially altered the SOC dynamics in the agro-ecosystems. With the $90 \%$ residue incorporation scenario, there were 86 counties gaining SOC and only 21 counties losing SOC in Shaanxi (Fig. 13). The magnitudes of the SOC increases driven by elevated residue incorporation rates were uneven across the domain. By comparison of the baseline scenario with the $90 \%$ residue incorporation scenario, the farmlands gaining the most SOC were located in the southern counties where the double-cropping systems (e.g., rice-winter wheat, corn-winter wheat etc.) provided more crop residue at an annual basis (Fig. 14).

Application of manure at rate of $500 \mathrm{~kg} \mathrm{C} / \mathrm{ha}$ also converted the Shaanxi farmland to a weak sink of atmospheric $\mathrm{CO}_{2}$. With this scenario, the changes in annual SOC storage

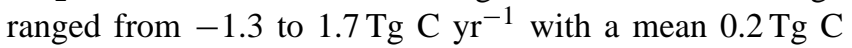
$\mathrm{yr}^{-1}$. The croplands benefited most with this approach were 


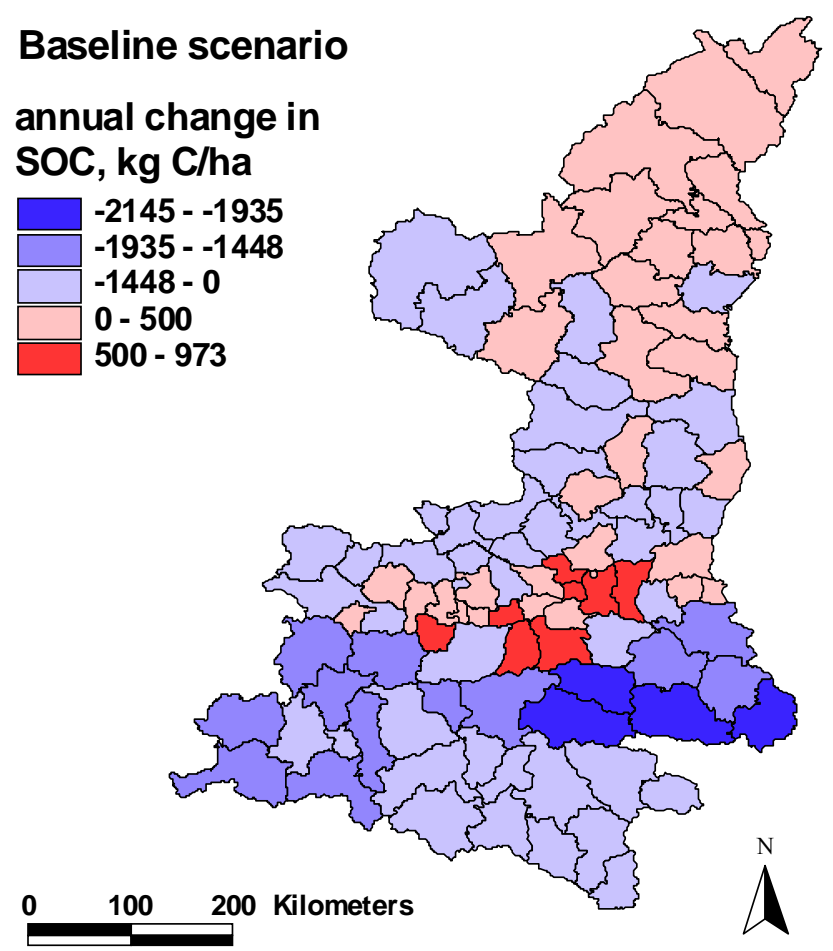

Fig. 12. Annual change values in SOC of baseline scenario (in $\mathrm{kg}$ $\mathrm{C} / \mathrm{ha}$ ). Most of the region showed decrease in SOC storage under current farm management.

located in the northern and middle zones where the climate was relatively dry and cool that sustain the low level of soil organic matter content (Fig. 15). The spatial difference in the SOC dynamics is in agreement with the results from the sensitivity tests reported in this paper.

\section{Discussions}

China possesses 1.3 million $\mathrm{km}^{2}$ of farmland mostly with long-term cultivation histories. For example, agricultural activities in Shaanxi Province, the domain selected for this modeling study, started as early as in the Qin Dynasty in 200 B.C. The survival of Chinese civilization from the millenniums mainly relied on its agriculture for food, fiber and energy. Traditionally, the Chinese farmers returned crop residue and manure from either animal's or human's wastes as much as possible back to the fields. It is the practices that sustained the soil fertility through the thousands-year cultivation. In $1950 \mathrm{~s}$, the traditional farming practices were challenged by the rapid changes in the socio-economic conditions in the country. The concerns about the long-term soil fertility were gradually replaced by the short-term profits gained from the land use. Especially, the significant improvement in availability and accessibility of synthetic fertilizers during the past several decades has gradually made the traditional practices abandoned in China. Based on the reports from

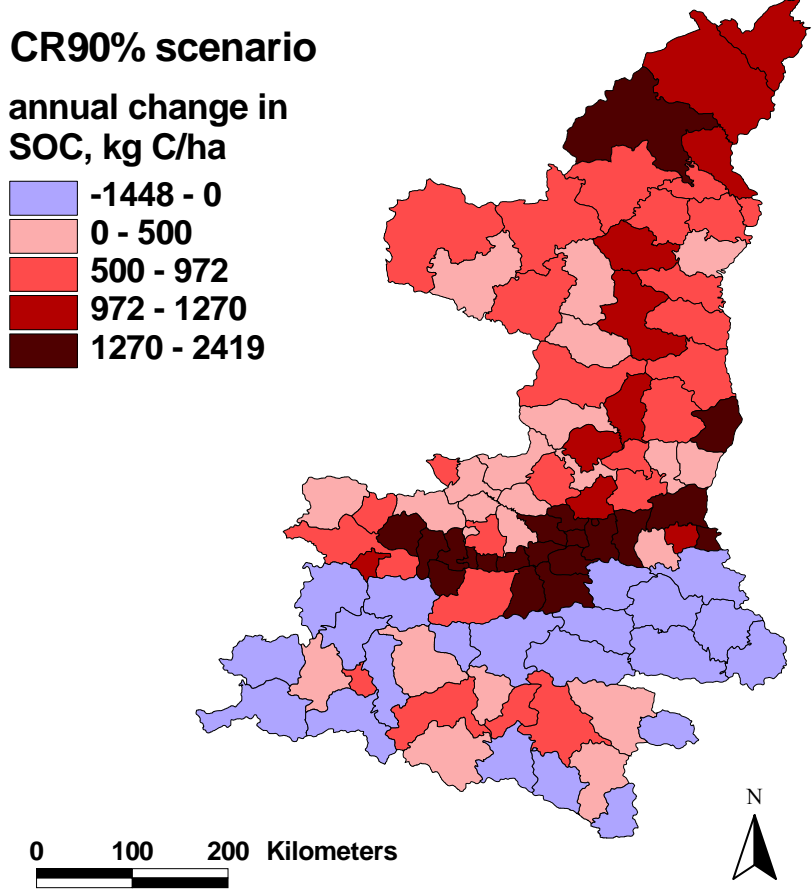

Fig. 13. Annual change values in SOC of crop residue 2 scenario (90\% crop residue application, shows in $\mathrm{kg} \mathrm{C/ha).} \mathrm{Farmland} \mathrm{soil}$ in Shaanxi increased SOC content distinctly with $90 \%$ crop residue incorporation. The north region with lower initial SOC content has great potential in carbon sequestration than south area and sequestrated more carbon.

many researchers (e.g., Leemans, 1999; Matson et al., 1997), this kind of changes in the farming management is, at least partially, responsible for the long-term decline in SOC in the agro-ecosystems. A former study for China also reported the negative SOC balances for most upland agroecosystems in the country ( $\mathrm{Li}, 2000)$. The losses of SOC not only diminish the soil sustainability but also elevate $\mathrm{CO}_{2}$ emissions from terrestrial ecosystems to the atmosphere. New regulations were recently issued by the Chinese authorities to encourage the farmers to resume the traditional farming practices (e.g., crop residue incorporation and farmyard manure amendment). It is apparently becoming an urgent, scientific issue for China to quantify the current SOC dynamics as well to optimize mitigation approaches for $\mathrm{C}$ sequestration at regional or national scale.

The paper reports a modeling study on quantifying the impacts of increase in crop residue incorporation and manure application on $\mathrm{C}$ sequestration in a region with longterm cultivation history. The results indicated that the alternative practices effectively converted the farmlands in the domain from a $\mathrm{C}$ source to a $\mathrm{C}$ sink. Altering the current farming practices by increasing residue incorporation rate to $90 \%$ or applying farmyard manure with $500 \mathrm{~kg} \mathrm{C} \mathrm{ha}^{-1}$ could sequester 2.1 or $0.2 \mathrm{Tg} \mathrm{C}$ (i.e., 7.7 or $0.73 \mathrm{Tg} \mathrm{CO}_{2}$ equivalent) per year. Since the modeled crop residue or farmyard manure 


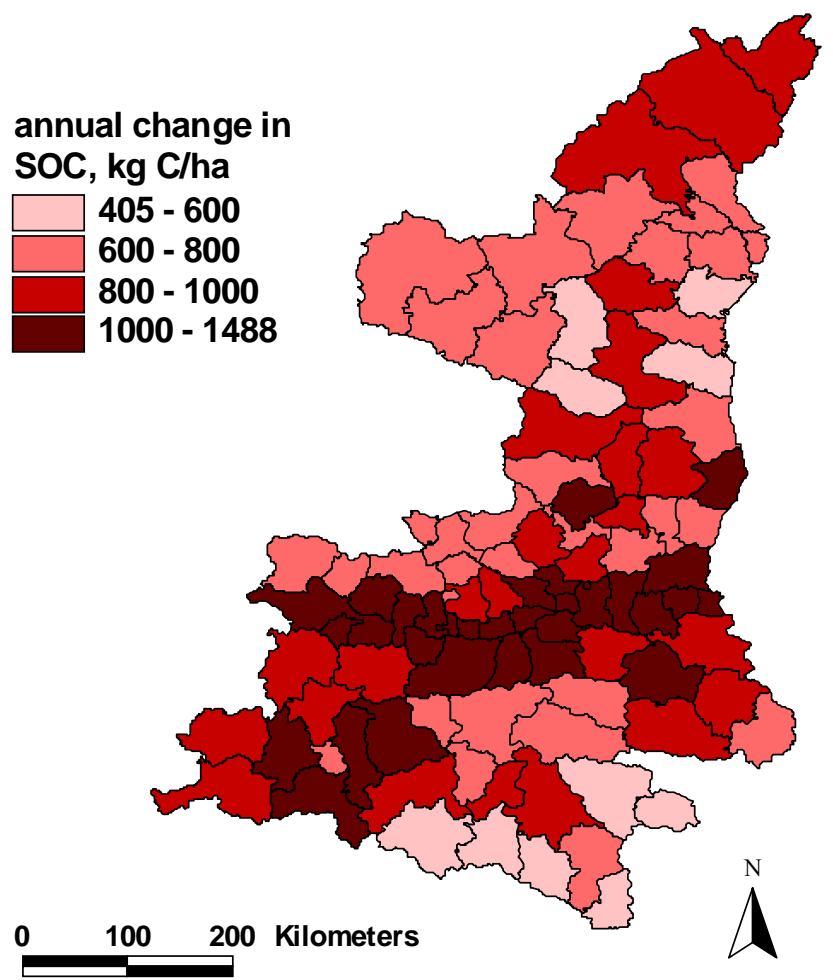

Fig. 14. Relative change in annual SOC change between crop residue 2 and baseline scenario (in $\mathrm{kg} \mathrm{C} / \mathrm{ha}$ ). Increase crop residue incorporation from $15 \%$ to $90 \%$ changed the SOC dynamics and enhanced SOC storage.

is actually available in the region, implementation of the two management alternatives should be feasible. The magnitude of $\mathrm{C}$ sequestration induced by the alternative management may vary when the modeled domain shifted from Shaanxi to other provinces in Northwest China, but the general trends should remain.

As a process-based model of soil $\mathrm{C}$ and $\mathrm{N}$ biogeochemistry, DNDC also predicts nitrous oxide $\left(\mathrm{N}_{2} \mathrm{O}\right)$ and methane $\left(\mathrm{CH}_{4}\right)$ emissions during the simulations of SOC dynamics that provides an opportunity for us to assess impacts of farming management alternatives on the net greenhouse gas emissions. Soil $\mathrm{N}_{2} \mathrm{O}$ emission is closely related to SOC content. Several former field or modeling studies indicated that increase in SOC content through no-till, manure application or other measures usually elevated $\mathrm{N}_{2} \mathrm{O}$ emissions due to the increased availability of dissolved organic carbon or inorganic nitrogen, two major nutrients for nitrifiers or denitrifiers (see a summary in Li et al., 2005). Methane production under anaerobic conditions or oxidation under aerobic conditions is also affected by SOC content (Wassmann et al., 1993). Results from this study indicated that, by converting the baseline practice to the alternative scenarios, the regional $\mathrm{N}_{2} \mathrm{O}$ emission increased from 0.0258 to 0.0259 and $0.0267 \mathrm{Tg} \mathrm{N}$ per year due to the increase in crop residue incorporation and the manure use, respectively. The increases in $\mathrm{N}_{2} \mathrm{O}$

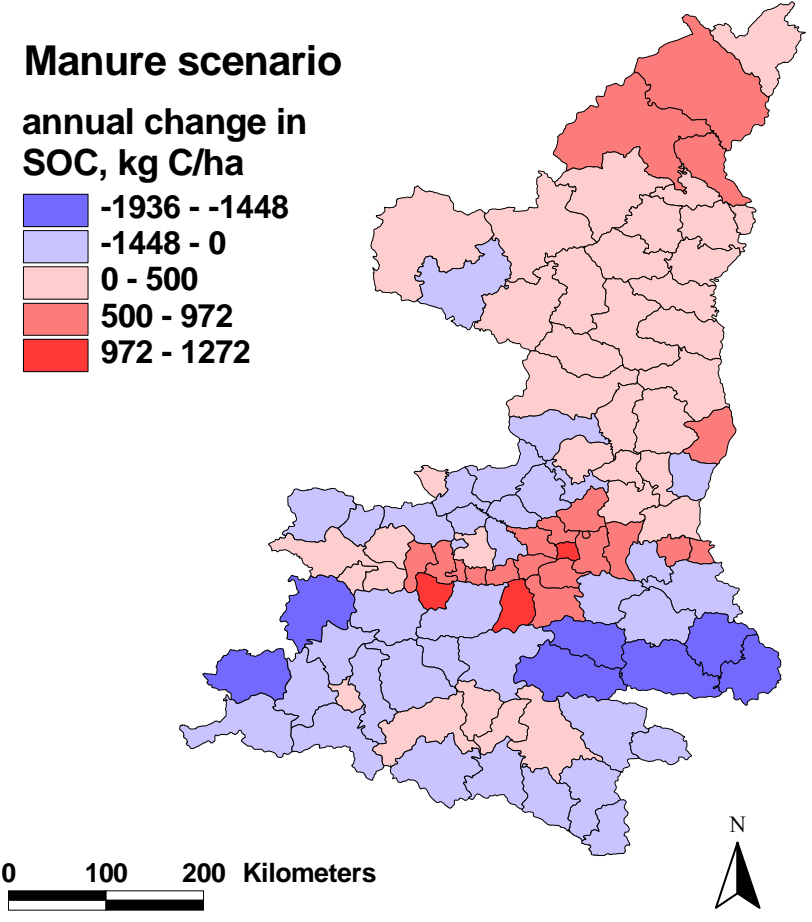

Fig. 15. Annual change values in SOC of manure scenario (in $\mathrm{kg}$ $\mathrm{C} / \mathrm{ha}$ ). Soil carbon input increasing through manure amendment improved soil properties and increased SOC content.

emissions (0.0001 and $0.0009 \mathrm{Tg} \mathrm{N}_{2} \mathrm{O}-\mathrm{N}$, respectively) are equivalent to 0.049 and $0.44 \mathrm{Tg} \mathrm{CO}_{2}$, which offset $0.6 \%$ and $60 \%$ of the benefits gained by the $\mathrm{C}$ sequestrations with the two alternative management practices, respectively. The results implied that amendment of manure could increase $\mathrm{N}_{2} \mathrm{O}$ emissions with a higher rate than crop residue incorporation as manure usually possesses much lower $\mathrm{C} / \mathrm{N}$ ratio than the crop litter. The regional $\mathrm{CH}_{4}$ flux was obtained by summing up the $\mathrm{CH}_{4}$ emissions from the wetland crops (i.e., paddy rice fields) and $\mathrm{CH}_{4}$ oxidations in the upland crops (e.g., wheat, corn etc.) across the entire agricultural lands in the modeled domain. The modeled results indicated that the impact of the alternative practices on $\mathrm{CH}_{4}$ is negligible with a total flux of about $0.17 \mathrm{Tg} \mathrm{CH}_{4}-\mathrm{C}$ across the different management scenarios for the croplands in Shaanxi Province.

Acknowledgements. We would like to thank Z. An and Z. Guo for helpful advice. We also thank the valuable comments or suggestions from the reviewers and the editors. Climate data used for this work were provided by the National Meteorological Agency of China. This research was supported by the National Basic Research Program of China (2004CB720200), and National Natural Sciences Foundation (No. 40599422, 40121303), and NASA's Terrestrial Ecology Project (NNG05GH 80G).

Edited by: T. Laurila 


\section{References}

Brown, L., Syed, B., Jarvis, S. C., Sneath, R. W., Phillips, V. R., Groulding, K. W. T., and Li, C.: Development and application of a mechanistic model to estimate emission of nitrous oxide from UK agriculture, Atmos. Environ., 36, 917-928, 2002.

Butterbach-Bahl, K., Stange, F., Papen, H., and Li, C.: Regional inventory of nitric oxide and nitrous oxide emissions for forest soils of southeast Germany using the biogeochemical model PnET-N-DNDC, J. Geophys. Res., 106(D24), 34 155-34 166, 2001.

Buyanovsky, G. A. and Wagner, G. H.: Carbon cycling in cultivated land and its global significance, Global Change Biology, 4, 131$141,1998$.

Cai, Z., Sawamoto, T., Li, C., Kang, G., Boonjawat, J., Mosier, A., Wassmann, R., and Tsuruta, H.: Field validation of the DNDC model for greenhouse gas emission in East Asian cropping systems, Global Biogeochem. Cycles, 17(4), 18-1-18-10, 2003.

Cardon, Z. G., Hungate, B. A., Cambardella, C. A., Chapin III, F. S., Field, C. B., Holland, E. A., and Mooney, H. A.: Contrasting effects of elevated $\mathrm{CO}_{2}$ on old and new soil carbon pools, Soil Biology \& Biochemistry, 33, 365-373, 2001.

Chinese Environmental Status Bulletin: Farmland/Soil, http://www. zhb.gov.cn/eic/649368303189360640/index.shtml, 2003.

Cole, C. V., Duxbury, J., Freney, J., Heinemeyer, O., Minami, K., Moiser, A., Paustian, K., Rosenberg, N., Sampson, N., Sauerbeck, D., and Zhao, Q.: Global estimates of potential mitigation of greenhouse gas emissions by agriculture, Nutrient Cycling in Agroecosystems, 49, 221-228, 1997.

Coleman, K., Jenkinson, D. S., Crocker, G. J., Grace, P. R., Klír, J., Körschens, M., Poulton, P. R., and Richter, D. D.: Simulating trends in soil organic carbon in long-term experiments using RothC-26.3, Geoderma, 81, 29-44, 1997.

Dai, R., Zhang, Z., and Dai, C.: Long-term test research of low yield red soil, in: National soil survey volume 1984-1991, China Workers Press (in Chinese), 82-95, 1994.

Duan, J., Li, X., Wang, G., and Li, B.: Modeling the Soil Change and process of Loess Plateau, China Agricultural Press (in Chinese), 2001.

Falkowski, P., Scholes, R. J., Boyle, E., Canadell, J., Canfield, D., Elser, J., Gruber, N., Hibbard, K., Högberg, P., Linder, S., Mackenzie, F. T., Moore III, B., Pedersen, T., Rosenthal, Y., Seitzinger, S., Smetacek, V., and Steffen, W.: The global carbon cycle: a test of our knowledge of Earth as a system, Science, 290, 291-296, 2000.

Follett, R. F.: Soil management concepts and carbon sequestration zin cropland soils, Soil \& Tillage Res., 61, 77-92, 2001.

Fu, J., Liu, G., Long, Y., and Wang, R.: Long-term test research of Taojiang soil, in: National croplands survey volume. China Agriculture Press (in Chinese), 330-337, 2003.

Grace, P. R.: The Waite permanent rotation trial, in: Evaluation of soil organic matter models using existing, long-term Datasets, edited by: Powlson, D. S., Smith, P., Smith, J. U., NATO ASI Series I, vol. 38, Springer, Heidelberg, pp 335-340, 1996.

Grant, B., Smith, W. N., Desjardins, R., Lemkc, R., and Li, C.: Estimated $\mathrm{N} 2 \mathrm{O}$ and $\mathrm{CO} 2$ emissions as influenced by agricultural practices in Canada, Climatic Change, 65(3), 315-332, 2004.

Huggins, D. R., Buyanovsky, G. A., Wagner, G. H., Brown, J. R., Darmody, R. G., Peck, T. R., Lesoing, G. W., Vanotti, M. B., and Bundy, L. G.: Soil organic $\mathrm{C}$ in the tallgrass prairie-derived region of the corn belt: effects of long-term crop management, Soil \& Tillage Res., 47, 219-234, 1998.

Institute of Soil Science: The Soil Atlas of China. Institute of Soil Science, Academia Sinica, Cartographic Publishing House, Beijing, 1986.

Janzen, H. H., Campbell, C. A., Izaurralde, R. C., Ellert, B. H., Juma, N., Mcgill, W. B., and Zentner, R. P.: Management effects on soil C storage on the Canadian prairies, Soil \& Tillage Res., 47, 181-195, 1998.

Jenkinson, D. S.: The Rothamsted long-term experiments: Are they still of use?, Agron. J., 83, 2-10, 1991.

Kiese, R., Li, C., Hilbert, D., Papen, H., and Butterbach-Bahl, K.: Regional application of PnET-N-DNDC for estimating the $\mathrm{N}_{2} \mathrm{O}$ source strength of tropical rainforests in the Wet Tropics of Australia, Global Change Biology, 11, 128-144, doi:10.1111/j.13652486.2004.00873x, 2004.

Leemans, R.: Land-use change and the terrestrial carbon cycle, in: Global Change Newsletter. The international GeosphereBiosphere Programme (IGBP): a study of global change of the International Council of Scientific Unions (ICSU), 24-26, 1999.

Li, C., Aber, J., Stange, F., Butterbach-Bahl, K., and Papen, H.: A process-oriented model of $\mathrm{N} 2 \mathrm{O}$ and $\mathrm{NO}$ emissions from forest soils: 1. Model development, J. Geophys. Res., 105(4), 43694384, 2000.

Li, C.: Conception and method of Biogeochemistry - Development of the DNDC model, Quat. Sci. (in Chinese), 21(2), 89-99, 2001.

Li, C., Frolking, S., and Butterbach-Bahl, K.: Carbon sequestration in arable soils is likely to increase nitrous oxide emissions, offsetting reductions in climate radiative forcing, Climatic Change, 72, 321-338, doi:10.1007/s10584-005-6791-5, 2005.

Li, C., Frolking, S., and Frolking, T. A.: A model of nitrous oxide evolution from soil driven by rainfall events: 1. Model structure and sensitivity, J. Geophys. Res., 97(D9), 9759-9776, 1992.

Li, C., Frolking, S., and Harriss, R.: Modeling carbon biogeochemistry in agricultural soils, Global Biogeochem. Cycles, 8(3), 237254, 1994.

Li, C., Frolking, S., and Harriss, R.: Modeling nitrous oxide emissions from agriculture: A Florida case study, Chemosphere, 28, 1401-1415, 1994.

Li, C.: Loss of soil carbon threatens Chinese agriculture: A comparison on agroecosystem carbon pool in China and the U.S., Quat. Sci. (in Chinese), 20(4), 345-350, 2000.

$\mathrm{Li}, \mathrm{C}$.: Modeling impact of agricultural practices on soil $\mathrm{C}$ and $\mathrm{N}_{2} \mathrm{O}$ emissions, in: Advances in Soil Science: Soil Management and the Greenhouse Effect, edited by: Lal, R., Kimble, J., Levine, E., and Stewart, B. A., Lewis Publishers, 101-112, 1995.

Li, C.: Modeling trace gas emissions from agricultural ecosystems, Nutrient Cycling in Agroecosystems, 58, 259-276, 2000.

Li, C., Mosier, A., Wassmann, R., Cai, Z., Zheng, X., Huang, Y., Tsuruta, H., Boonjawat, J., and Lantin, R.: Modeling greenhouse gas emissions from rice-based production systems: Sensitivity and upscaling, Global Biogeochem. Cycles, 18, 19-1-1919, 2004.

Li, C., Narayanan, V., and Harriss, R.: Model estimates of nitrous oxide emissions from agricultural lands in the United States, Global Biogeochem. Cycles, 10, 297-306, 1996.

Li, C., Zhuang, Y., Cao, M., Gri, I. P. M., Dai, Z., Frolking, S., Moore, B., Salas, W., Song, W., and Wang, X.: Comparing a national inventory of $\mathrm{N}_{2} \mathrm{O}$ emissions from arable lands in China de- 
veloped with a process-based agro-ecosystem model to the IPCC methodology, Nutr. Cycl. Agroecosystems, 60, 159-175, 2001.

Li, C., Zhuang, Y., Frolking, S., Galloway, J., Harriss, R., Moore III, B., Schimel, D., and Wang, X.: Modeling soil organic carbon change in croplands of China, Ecological Applications, 13(2), 327-336, 2003.

Li, L. and Pan, G.: Farmland SOC dynamic research in Jiangsu province, Chinese Agricultural Science Bulletin (in Chinese), 15(6), 41-44, 1999.

Matson, P. A., Parton, W. J., Power, A. G., and Swift, M. J.: Agricultural intensification and ecosystem properties, Science, 277, 504-509, 1997.

Ministry of Agriculture/Division of Energy Project Expert Team: Assessment of Biomass Resource Availability in China, China Environmental Science Press (in Chinese), Beijing, 1997.

National Soil Survey Office of China: Soils in China, vol. 1-6, Agricultural Publishing House, Beijing (in Chinese), 1993-1997.

Pan, G., Li, L., Zhang, X., Dai, J., Zhou, Y., and Zhang, P.: Soil organic carbon storage of China and the sequestration dynamics in agricultural lands, Adv. Earth Sci. (in Chinese), 18(4), 609618, 2003.

Pan, G. and Zhao, Q.: Study on evolution of organic carbon stock in agricultural soils of China: facing the challenge of global change and food security, Adv. Earth Sci. (in Chinese), 20(4), 384-393, 2005.

Pathak, H., Li, C. S., and Wassmann, R.: Greenhouse gas emissions from Indian rice fields: calibration and upscaling using the DNDC model, Biogeosciences, 2, 113-123, 2005, http://www.biogeosciences.net/2/113/2005/.

Paustian, K., Babcock, B., Kling, C., Hatfield, J., Lal, R., Mccarl, B., Post, W. M., Mosier, A., Rice, C., and Robertson, G. P.: Agricultural mitigation of Greenhouse gases: science and policy options, National Conference On Carbon Sequestration, 2001.

Paustian, K., Six, J., Elliott, E. T., and Hunt, H. W.: Management options for reducing $\mathrm{CO}_{2}$ emissions from agricultural soils, Biogeochemistry, 48, 147-163, doi:10.1023/A:1006271331703, 2000.

Peng, C., Apps, M. J., Price, D. T., Nalder, I. A., Halliwell, D. H.: Simulating carbon dynamics along the boreal forest transect case study (BFTCS) in central Canada: 1. Model testing, Global biogeochem. cycles, 12(2), 381-392, 1998.

Peng, K.: Contradictions and countermeasures in the development of farming system, Journal of Shandong Agricultural University (Social Science) (in Chinese), 3(3), 43-47, 2001.

Post, W. M. and Kwon, K. C.: Soil carbon sequestration and landuse change: processes and potential, Global Change Biology, 6, 317-327, 2000.

Qiu, J., Wang, L., Tang, H., Li, H., and Li, C.: Study on the situation of soil organic carbon storage in arable lands in northeast China, Scientia Agricultural Sinica, 37(8), 1166-1171, 2004.

Saggar, S., Andrew, R. M., Tate, K. R., Hedley, C. B., and Townsend, J. A.: Simulation of nitrous oxide emissions from New Zealand dairy-grazed pastures and its mitigation strategies, in: Proceedings of the 3rd International Methane and Nitrous Oxide Mitigation Conference, 17-21 November, Beijing, China, p. 461-468, 2003.

Schimel, D., Melillo, J., Tian, H., McGuire, A. D., Kicklighter, D., Kittel, T., Rosenbloom, N., Running, S., Thornton, P., Ojima, D., Parton, W., Kelly, R., Sykes, M., Neilson, R., and Rizzo, B.:
Contribution of increasing $\mathrm{CO}_{2}$ and climate to carbon storage by ecosystems in the United States, Science, 287, 2004-2006, 2000.

Sellers, P. J., Dickinson, R. E., Randall, D. A., Betts, A. K., Hall, F. G., Berry, J. A., Collatz, G. J., Denning, A. S., Mooney, H. A., Nobre, C. A., Sato, N., Field, C. B., and Henderson-Sellers, A.: Modeling the exchanges of energy, water, and carbon between continents and the atmosphere, Science, 275, 502-509, 1997.

Shaanxi Department of Agriculture, Shaanxi Agricultural Regional Planning Council: Shaanxi Province Plant Resources and Regional Planning, Shaanxi Technology Press (in Chinese), 1987.

Shan, L. and Chen, G.: Theories and practices of upland agriculture in the Loess Plateau, Science Press, Beijing (in Chinese), p. 256263, 1993.

Sherrod, L. A., Peterson, G. A., Westfall, D. G., and Ahuja, L. R.: Cropping intensity enhances soil organic carbon and nitrogen in a no-till agroecosystem, Soil Sci. Soc. Amer., 67, 1533-1543, 2003.

Smith, P., Smith, J. U., Powlson, D. S., McGill, W. B., Arah, J. R. M., Chertov, O. G., Coleman, K., Franko, U., Frolking, S., Jenkinson, D. S., Jensen, L. S., Kelly, R. H., Klein-Gunnewiek, H., Komarov, A. S., Li, C., Molina, J. A. E., Mueller, T., Parton, W. J., Thornley, J. H. M., and Whitmore, A. P.: A comparison of the performance of nine soil organic matter models using datasets from seven long-term experiments, Geoderma, 81, 153$225,1997$.

Smith, W. N., Grant, B., Desjardins, R. L., Lemke, R., and Li, C.: Estimates of the interannual variations of $\mathrm{N}_{2} \mathrm{O}$ emissions from agricultural soils in Canada, Nutrient Cycling in Agroecosystems, 68(1), 37-45, 2004.

Tang, J.: Soil fertility changes of Guangdong high yield farmland, in: National croplands survey volume, China Agriculture Press (in Chinese), 80-84, 2003.

Sun, C., Gao, F., and Qu, J.: Latest knowledge on Global Climate Change - IPCC third assessment report, ZiRan ZaZhi (in Chinese), 24(2), 114-122, 2001.

Wairiu, M. and Lal, R.: Soil organic carbon in relation to cultivation and topsoil removal on sloping lands of Kolombangara, Solomon Islands, Soil \& Tillage Res., 70, 19-27, 2003.

Wang, S., Tian, H., Liu, J., and Pan, S.: Pattern and change of soil organic carbon storage in China: 1960s-1980s, Tellus, 55B, 416-427, 2003.

Wassmann, R., Papen, H., and Rennenberg, H.: Methane emission from rice paddies and possible mitigation strategies, Chemosphere, 26, 201-217, 1993.

Wu, H., Guo, Z., and Peng, C.: Land use induced changes of organic carbon storage in soils of China, Global Change Biology, 9, 305315, 2003.

Xu-Ri, Wang, M., and Wang, Y.: Using a modified DNDC model to estimate $\mathrm{N}_{2} \mathrm{O}$ fluxes from semi-arid grassland in China, Soil Biology and Biochemistry, 35, 615-620, 2003.

Yang, Y.: Shaanxi Statistical Yearbook, China Statistics Press (in Chinese), Beijing, 2001.

Zhang, M. and He, Z.: Long-term changes in organic carbon and nutrients of an Ultisol under rice cropping in southeast China, Geoderma, 118, 167-179, 2004. 